\title{
EXPLORING RISK-ADJUSTED FISCAL SUSTAINABILITY ANALYSIS FOR ASIAN ECONOMIES
}

George Kopits, Benno Ferrarini, and Arief Ramayandi

NO. 483

May 2016
ADB ECONOMICS WORKING PAPER SERIES 


\section{Exploring Risk-Adjusted Fiscal Sustainability Analysis for Asian Economies}

George Kopits, Benno Ferrarini, and Arief Ramayandi

No. 483 | May 2016
George Kopits (george.kopits@wilsoncenter.org) is senior scholar in the Woodrow Wilson International Center for Scholars, Benno Ferrarini

(bferrarini@adb.org) and Arief Ramayandi (aramayandi@adb.org) are senior economists in the Economic Research and Regional Cooperation Department (ERCD) of the Asian Development Bank.

The authors would like to thank Dennis Sorino, Michael Angelo Cokee, and participants of the ERCD seminar series for valuable comments. 
Asian Development Bank

6 ADB Avenue, Mandaluyong City

1550 Metro Manila, Philippines

www.adb.org

(C) 2016 by Asian Development Bank

May 2016

ISSN 2313-6537 (Print), 2313-6545 (e-ISSN)

Publication Stock No. WPS168031-2

The views expressed in this paper are those of the authors and do not necessarily reflect the views and policies of the Asian Development Bank (ADB) or its Board of Governors or the governments they represent.

ADB does not guarantee the accuracy of the data included in this publication and accepts no responsibility for any consequence of their use.

By making any designation of or reference to a particular territory or geographic area, or by using the term "country" in this document, $A D B$ does not intend to make any judgments as to the legal or other status of any territory or area.

Note: In this publication, "\$” refers to US dollars.

The ADB Economics Working Paper Series is a forum for stimulating discussion and eliciting feedback on ongoing and recently completed research and policy studies undertaken by the Asian Development Bank (ADB) staff, consultants, or resource persons. The series deals with key economic and development problems, particularly those facing the Asia and Pacific region; as well as conceptual, analytical, or methodological issues relating to project/program economic analysis, and statistical data and measurement. The series aims to enhance the knowledge on Asia's development and policy challenges; strengthen analytical rigor and quality of ADB's country partnership strategies, and its subregional and country operations; and improve the quality and availability of statistical data and development indicators for monitoring development effectiveness.

The ADB Economics Working Paper Series is a quick-disseminating, informal publication whose titles could subsequently be revised for publication as articles in professional journals or chapters in books. The series is maintained by the Economic Research and Regional Cooperation Department. 


\section{CONTENTS}

TABLES AND FIGURES $\quad$ iv

ABSTRACT

$\begin{array}{ll}\text { I. INTRODUCTION } & 1\end{array}$

II. THE CASE FOR RISK-ADJUSTED FISCAL SUSTAINABILITY 2

III. DETERMINISTIC METHODS 4

$\begin{array}{lll}\text { IV. } & \text { STOCHASTICMETHODS } & 7\end{array}$

V. ROAD MAP FOR APPLICATION TO ASIAN ECONOMIES

$\begin{array}{ll}\text { VI. SUMMARY AND CONCLUSION } & 20\end{array}$

$\begin{array}{ll}\text { APPENDIX } & 23\end{array}$

$\begin{array}{lr}\text { REFERENCES } & 29\end{array}$ 


\section{TABLES AND FIGURES}

\section{TABLES}

$1 \quad$ Comparison of Stochastic Methods 14

$2 \quad$ Summary of the Intertemporal Balance Sheet of the Public Sector 17

3 Ecuador: Risk-Adjusted Balance Sheet of the Public Sector, 200018

4 CCA-Based Sovereign Risk-Adjusted Balance Sheet 19

A.1 Risk Matrix and Data Availability 25

A.2 Source of Contingent Risks Classification 26

A.3 Data Sources of Risk Variables 27

\section{FIGURES}

$1 \quad$ Asian Countries Classification of Fiscal Risks, 2015

$2 \quad$ Selected Asian Countries: Sovereign Risk Premium, January 2007-December $2015 \quad 4$

3 Southeast Asian Countries: VAR-Based Fan Charts, 2016-2020 8

$4 \quad$ Ecuador: Value-at-Risk Public Sector Net Worth, 2000 10

5 The Republic of Korea and the Philippines: Sovereign Default Probability and CDS Spreads, 2002-2004 


\begin{abstract}
The paper explores risk-based fiscal analytical approaches to complement a standard debt sustainability analysis when applied under conditions of risk and uncertainty. To outline a possible road map for risk-adjusted fiscal sustainability analysis, the paper first examines the types of vulnerability faced by different emerging economies in Asia and reviews a range of stochastic methods that attempt to explicitly incorporate risk in their analysis. Drawing on international experience, we note that the usefulness of applying a stochastic approach hinges on policy makers' capacity to identify the sources and extent of risks in assessing fiscal sustainability, which should then allow them to simulate the impact of a hypothetical corrective action on the baseline trajectory of debt or net worth and on its stochastic distribution, including fat-tail risks of default.
\end{abstract}

Keywords: fiscal sustainability, risk-based fiscal analysis, sovereign debt, stochastic approach

JEL codes: D81, E62, G13, H63 


\section{INTRODUCTION}

Over the past 2 decades, Asian economies have experienced the impact of at least three shocks: in the second half of 1990s, their own homegrown financial crisis; since the late 2000s, the effects of the global financial crisis and the ensuing so-called great recession; and more recently, continuing repercussions of the recession onto a slowdown in the People's Republic of China and the accompanying sharp decline and volatility in primary commodity prices. Although these episodes had differing consequences across Asia, there are common roots for emerging market economies in the continent: namely, an unprecedented global integration and financial liberalization, paralleled by access of governments to a deepening secondary financial market. ${ }^{1}$

Meanwhile, in the political economy arena, fiscal developments that began much earlier in Western Europe and Latin America were beginning to take hold in a number of Asian economies as well. Public expenditures to finance relatively rigid social entitlements and other public services-partly driven by deteriorating demographics - as well as defense and security, are beginning to rise against the limits to taxation. ${ }^{2}$ If unchecked, the narrowing of fiscal space, along with some crisis episodes, may eventually lead to a buildup of public indebtedness in some of these economies. Given the vulnerability to future shocks and the prospect of a further rise in public debt, governments are increasingly aware of the need to adopt prudent fiscal policies and correct deep-seated institutional weaknesses. As a first step in this endeavor, they are well advised to assess fiscal sustainability under well-identified conditions of risk and uncertainty.

The standard framework governments and international bodies, including the Asian Development Bank, employ for debt sustainability analysis (DSA) is ill-suited to the assessment of fiscal sustainability under risk. Risk-based approaches have emerged in the recent literature and practice, but have not entered the mainstream of fiscal analysis, some hampered by computational complexities and heavy data requirements. This paper reviews the existing methods and suggests ways to adopt appropriate techniques for the context of fiscal vulnerabilities of countries in developing Asia, with the purpose of helping future policy making and analysis.

The rest of the paper is organized as follows. The next section examines the arguments for assessing fiscal sustainability under uncertainty, taking into account the types of vulnerability faced by different emerging market economies in Asia. The third section is a survey of the literature on deterministic approaches to fiscal sustainability analysis and its limitations in the real world. This is followed by a review of stochastic methods that attempt to explicitly incorporate risk in the analysis. The fifth section outlines a road map for risk-adjusted fiscal sustainability analysis (RFSA) to be considered for future application in Asian emerging market economies. The paper concludes with an overview of implications for managing and mitigating fiscal risks, drawing on the international experience.

See Mussa and Richards (2000) on the evolution and characteristics of emerging markets. See Carrasco, Gokarn, and Mukhopadhyay (2014) for a discussion of capital account liberalization in Asia.

2 See Park, Lee, and Lee (2015) for a discussion of the growing demand in Asia for fiscal policy to stem rising inequality and foster inclusive growth in the region. 


\section{THE CASE FOR RISK-ADJUSTED FISCAL SUSTAINABILITY}

By now it is widely recognized that high public sector indebtedness, relative to economic activity, is inimical to economic growth and stability. Over the years, the growth-depressing effect of high public debt-at a lower threshold in emerging market economies than in advanced economies-as well as the reciprocal causality between high debt and financial crises, has been documented with statistical and anecdotal evidence. ${ }^{3}$ As a result, policy makers especially in emerging market economies have become increasingly concerned about how sustainable is public debt. Currently, this concern has reached a peak in the wake of the global financial crisis that has led to mounting public debt in a number of advanced economies as well. ${ }^{4} \mathrm{~A}$ major lesson is the need to adopt a fiscal policy stance aimed at containing public debt with a view to regaining sustainability, as well as to launch structural reform measures to promote efficiency and growth. In addition, the creation of institutions, including macroprudential tools, to mitigate risk is clearly necessary.

In response to these developments, the past decade or so has given way to experimentation with increasingly sophisticated techniques at assessing fiscal sustainability, possibly incorporating the vulnerability of the economy to various internally-generated and exogenous risks. The relevance of such techniques is underscored for Asian economies that are exposed to a variety of general, specific, and even systemic fiscal risks-derived from the typology popularized in New Zealand's pioneering identification and measurement of fiscal risks. ${ }^{5}$

Following broadly this classification, the Venn diagram in Figure 1 maps Asian developing economies into four different important sources of fiscal risk that may affect their fiscal sustainability: macroeconomic vulnerabilities, structural factors, contingent liabilities, and demographic pressures. ${ }^{6}$ Macroeconomic risks stem from vulnerabilities in output, prices, and fiscal-related factors. Structural risks cover those pertaining to the economy's exposure to natural disasters and dependence on the external sector, including on exports of primary commodities. Contingent risks include those related to vulnerability to the finance sector and state-owned enterprises. Demographic risks are related to population aging and its economic impact in the coming decades.

To be classified into a particular risk category, a country is reported to have moderate concerns over the risk or the vulnerability of at least half of the indicators, or high concern about a single indicator, belonging to that category (Table A1). The degree of concern over each indicator, however, may change over time as they are determined based on information available from the latest International Monetary Fund (IMF) Article IV consultation documents and the latest data available for each country. Cambodia, for example, as of 2015 is classified in the macroeconomic vulnerability category because of a high concern on its increasing and persistent primary balance deficits over the past 5 years and in IMF World Economic Outlook projections for the coming 5 years. The country also falls in the structural risks category due to high concern on the natural disaster risks and concerns over the ratio of external debt to gross domestic product (GDP) and share of primary commodities in total exports.

3 Findings by Reinhart and Rogoff (2009) were corroborated by Cecchetti, Mohanty, and Zampoli (2011) with robust estimates on a homogeneous country sample over a recent period and encompassing a broad institutional coverage of the public sector.

4 A significant increase in the public debt ratio was recorded from before to after the Asian crisis: Indonesia, 78\%; the Republic of Korea, 45\%; and the Philippines, 55\%. During the euro crisis, the steepest rise in the debt ratio was experienced in Ireland with $98 \%$. The rise in the debt ratio is attributable not only to bank recapitalization, but also to the decline in economic activity.

5 See also the three-way distinction of economic, technical, and political risks in Kopits (2004).

6 A detailed breakdown of the classification is provided in Appendix I. 
Figure 1: Asian Countries: Classification of Fiscal Risks, 2015

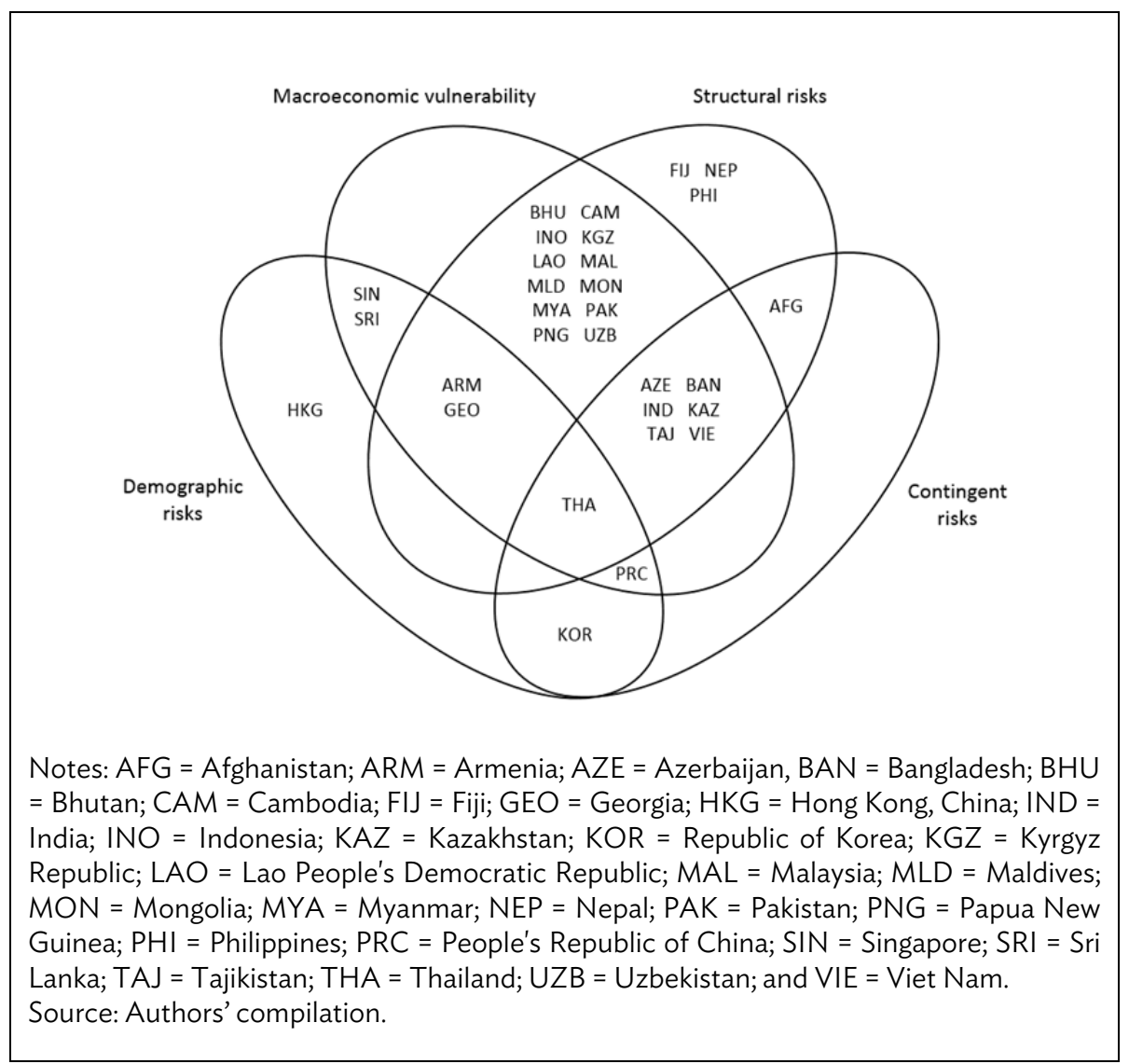

The range of the exposure over different risk factors varies across Asia. On one side, as of 2015, Thailand appears to be the only country with concerns over all the sources of risk. Unstable and decreasing GDP growth rates, relatively high public debt to GDP ratio, and a high degree of fiscal decentralization raised some concerns over the macroeconomic vulnerability aspects of Thailand's government budget; high share of external debt and high risk of natural calamities are translated into a concern on the country's structural condition; relatively large size of households debt and exposure to the state-owned enterprises raises concerns over contingencies; and rapidly increasing share of elderly population induces demographic vulnerability. On the other side, Hong Kong, China; Fiji; Nepal; and the Philippines only appear with a concern over a single source of risk. Fiji, Nepal and the Philippines are exposed to concerns over structural risk mainly because of exposure to climate change, while Hong Kong, China is exposed to concerns over its rapidly aging population.

Some countries' position on the map also appear debatable as they are heavily dependent on special conditions when the assessment is made. Afghanistan's macroeconomic prospects, for example, appear to be relatively stable at the time of observation despite the country's reliance on a fairly steady flow of foreign aid to finance its external and fiscal imbalances. As a result, the country is seen exposed to both structural and contingent risks, while the issue of macroeconomic vulnerability appears less severe. 
A rough gauge of the sovereign risk that can be regarded as a summary of the foregoing risks, as perceived by financial markets subject to momentary fluctuations in sentiment, is the risk premium charged on government paper in the secondary market. The risk premium is measured by the spread in yield on a long-term bond issued by the government and the yield on a comparable maturity bond regarded as riskless. For example, the risk premium for selected economies in Southeast Asia (Figure 2) shows far more volatility for more vulnerable countries, as classified above.

\section{Figure 2: Selected Asian Countries: Sovereign Risk Premium,} January 2007-December 2015

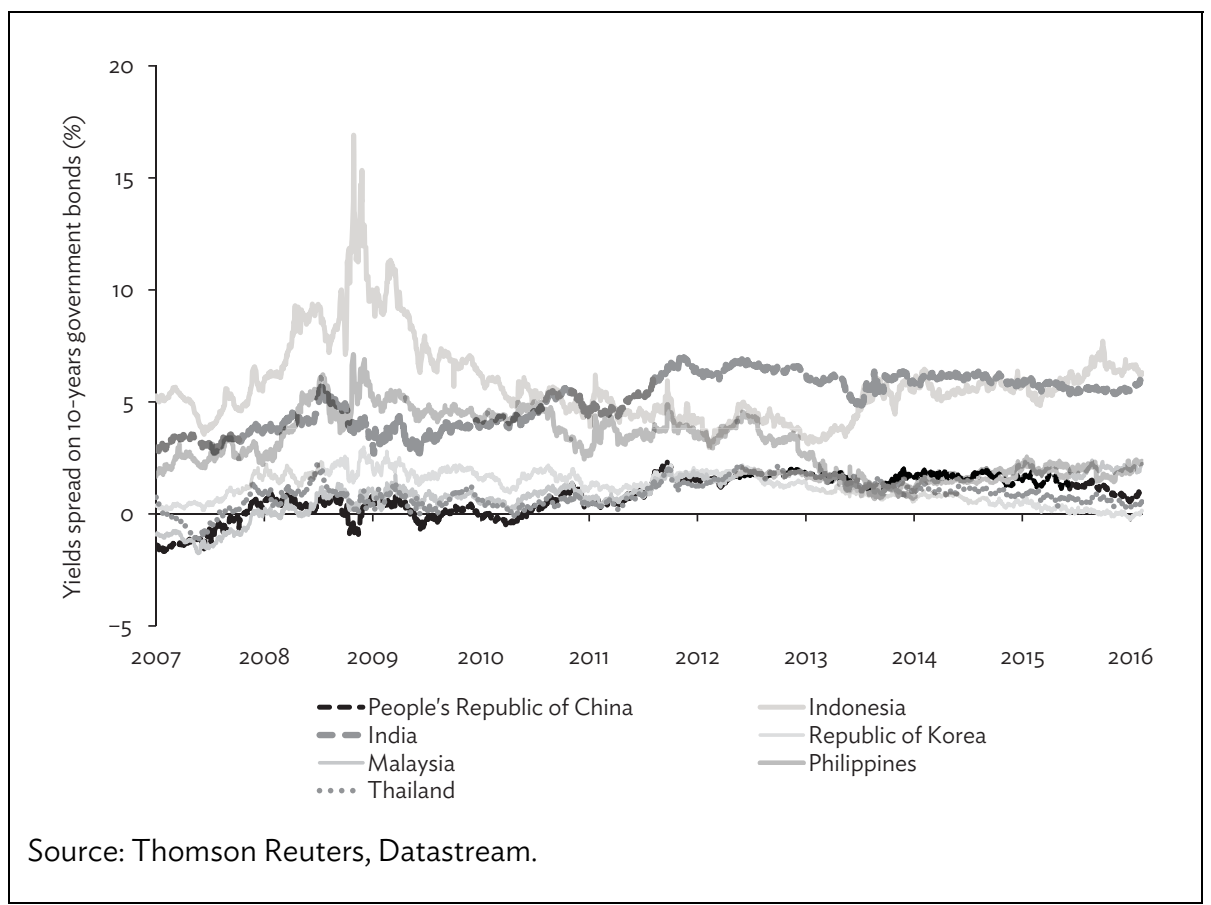

\section{DETERMINISTIC METHODS}

Fiscal sustainability is a multifaceted and somewhat elusive concept, open to a variety of analyses, interpretations, and applications. ${ }^{7}$ Under a catch-all definition, it signifies the government's ability to meet its obligations over a well-defined time horizon, without altering policies, institutions, or the structure of the public sector. Assessment of fiscal sustainability is typically conducted ex ante, projecting or assuming the future trajectory in the country's public finances on the basis of past developments.

At an extreme, actual fiscal sustainability is only known ex post, that is, when a government defaults on its obligations - that occasionally can occur in the form of a strategic default. In this sense, comparisons are drawn with respect to bankruptcy in the private sector. However, such comparisons are invalid insofar as the government, unlike households or firms, much before reaching the default

7 These can be found in a rapidly growing literature, dedicated mostly to deterministic approaches. For a sample, see the collections of studies edited by Burnside (2005) and Banca d'Italia (2008), and those focusing in Asian economies by Ferrarini, Jha, and Ramayandi (2012). 
event, has very broad latitude-both over time and in space - to alter policy course and launch reforms whereby it can restore sustainability, and prevent default.

There are at least four basic methods, including numerous indicators, that are/have been used to determine fiscal sustainability by academics, governments, and international financial institutions: the public debt ratio, public debt stability, baseline debt projection, and public sector solvency. In some respects, they overlap each other and are treated interchangeably, but in fact they can be distinguished from one another for analytical and practical purposes.

Perhaps the oldest method at assessing fiscal sustainability consists simply of observing the evolution of public debt as a ratio of GDP. For subnational governments, the debt usually is expressed as a ratio of own revenue, which represents collateral. It is presumed that the ratio provides prima facie evidence of the government's future capacity to service its liabilities. The ratio is then used against a normative standard that purports to be a prudential threshold for sustainability. In a cross-country survey of evidence on debt ratios and defaults, the IMF (2003b, chapter 3 ) inquires as to the sustainable debt ratio in emerging market economies. In the wake of the recent crisis, the IMF (2011) proposed more stringent analysis of member governments when the debt ratio exceeds $60 \%$. In the European Union (EU), since the establishment of the Stability and Growth Pact, member countries are expected to maintain the public debt ratio at (or, if above, reduce to) $60 \%$ limit; it is against this metric that the European Commission publishes an official estimate of gross general government liabilities. Academics also consider the debt ratio as an indication of vulnerability. ${ }^{8}$

An alternative, more analytical, method is to calculate the stability of the debt ratio over the medium term, derived from debt dynamics. All else being unchanged, the public debt ratio is driven by the interplay of the growth rate and the interest rate, which over time can be stabilized by an appropriate level of the primary budget balance. Hence, the debt stability condition is expressed by the equivalence of the primary surplus, as a ratio to GDP, and the difference between the interest rate and the growth rate. This familiar condition is often used for normative purposes to determine the minimum primary surplus necessary to maintain debt stability, and as such, it can be viewed as a complement to a prescribed ceiling on the debt ratio. ${ }^{9}$ For example, under Brazil's Fiscal Responsibility Law, the government can be required to maintain a primary surplus that is sufficient not only for stabilizing, but also for reducing the debt ratio to reach a target debt ratio over a specified number of years. Pursuant to the revised Stability and Growth Pact, EU member governments are now bound by a similar debt rule. In several Asian countries with fiscal responsibility laws in place, such as India and Indonesia, adherence with fiscal rules affects the debt ratio indirectly through fiscal deficit limits. ${ }^{10}$

A third, possibly the most popular, method-initially applied to determine the sustainability of public pension systems - entails projecting a medium- or long-term baseline scenario of the debt ratio, in the context of a set of critical macroeconomic, demographic, and environmental assumptions about future developments. "As the name suggests, the baseline scenario assumes no policy change over the scenario horizon. A major advantage of this approach over the preceding ones is that it permits tracing the time profile of the debt ratio that may reflect the potential impact of aging, as well as longer gestating reform measures in pensions, healthcare, taxation, or various contingent liabilities, which will

\footnotetext{
For instance, Hausmann (2004) compared the relationship between the debt ratio and credit ratings across countries. IMF (1996, p. 51) provided estimates of the debt-stabilizing primary surplus over a 15-year period.

10 For background on the design of fiscal rules in India and Indonesia, see Kopits et al. (1993) and Kopits (2001), respectively.

11 This approach was first applied to assess the sustainability of Hungary's public pensions by Kopits et al. (1990).
} 
be triggered in the distant future. By the same token, it permits quantitative simulations of the likely effect of well-specified changes in fiscal policy.

Baseline scenarios were the first to be used for incorporating risks to the debt burden stemming from macroeconomic shocks. The effect of such risks, which widen over time into the future, can be illustrated with fan charts; hence, the approach is often named fan-chart approach to debt sustainability. Over the past decade, the IMF $(2002,2003 a)$ has been applying on a routine basis such stress or sensitivity tests under the so-called debt sustainability analysis (DSA) in Article IV consultations with member countries, portrayed in a fan chart. Specifically, the DSA template has been used to simulate the impact of three types of shocks on the debt ratio: one and two standard deviations of macroeconomic variables (GDP, inflation, primary balance, external financial flow) from their historical averages; 30\% exchange rate devaluation; and realization of (undefined) contingent liabilities totaling $10 \%$ of GDP.

In response to the financial crisis, for member countries with market access, the IMF (2011) called for greater scrutiny of baseline assumptions, broader coverage of public debt, additional policy scenarios, and qualitative assessments to capture more fully risks, including those stemming from contingent liabilities. Largely drawing on these recommendations, the IMF (2013) issued detailed staff guidelines for a revised DSA template that includes fan charts with stress tests for the debt ratio and financing needs, simulating shocks in real GDP, real interest rate, real exchange rate, deflation, customized contingent liabilities, and primary balance. The shocks are generated by variance and covariance of each variable, on the basis of historical country data, depicted in probabilistic scenarios around the baseline scenario over a 5-year horizon. In addition, the template provides for an estimate of debt profile vulnerabilities, as compared to international benchmarks, in the country's bond spread, external financing requirement, change in short-term debt, debt held by nonresidents, and foreigncurrency denominated debt. A composite of these estimates is presented in a "heat map" indicating high, moderate or low risk for each module, which can be regarded as a fiscal risk assessment matrix. ${ }^{12}$

Along similar lines, applying a somewhat simpler approach for assessing risk over a mediumterm scenario for flow variables of fiscal performance (public sector net borrowing, cyclically-adjusted current budget balance), as a ratio to GDP, the United Kingdom (UK) Office for Budget Responsibility (2012) publishes annually fan charts around the projected baseline. The fan charts, estimated on the basis of the distribution of past forecast errors of each variable, including GDP, are interpreted as portraying the probability that the government will meet its fiscal target over a 5-year period. Essentially, instead of testing for an arbitrary set of shocks, these fan charts are intended to assess the sensitivity of various indicators of fiscal outcome to a historical pattern of shocks, as reflected in past forecast errors. However, past forecast errors, measured over an extended period, are likely to be obsolete in the future, given changes in technology and data.

The fourth method at analyzing fiscal sustainability seeks to determine the solvency of the public sector on the basis of an intertemporal balance sheet, whereby this is also called balance-sheet method. Instead of focusing on aggregate gross liabilities, sustainability is assessed in terms of the intertemporal net worth of the public sector calculated from the present value of assets less liabilities

12 Moreover, under Article IV consultations, IMF (2013, 2015a) prescribes elaboration of a risk assessment matrix (RAM) that depicts the subjective staff views on the likelihood of specified macroeconomic and financial shocks and their impact in each member country: "low" at less than 10\% probability, "medium" from 10 to 30\% probability, and "high" at above $30 \%$ probability. Both the fiscal "heat map" and the RAM are reminiscent of the pedagogically useful fiscal matrix designed earlier by Polackova and Schick (2002). 
of the public sector. By definition, such an intertemporal balance sheet includes the present value of all contingent assets and liabilities as well. This approach was implemented by IMF staff in half a dozen emerging market and advanced economies in the context of its surveillance function, yet was not adopted to serve as a template mainly because of data limitations. In the IMF, the first attempt at estimating an intertemporal balance sheet since 2000, for Ecuador, was followed chronologically by estimates for Germany, Switzerland, Sweden, and immediately before being hit by the crisis, Greecelisted in IMF (2015b). Quite independently, the balance-sheet method has been applied also in Colombia and Venezuela by Easterly and Yuravlivker (2002). The most detailed and comprehensive application is published annually by the UK Office for Budget Responsibility (2015) in the UK. Because of differences in valuation and institutional coverage, estimates are not fully comparable across countries. Yet, under the balance-sheet method, being the most rigorous test of fiscal sustainability, some of these governments were found to be insolvent, as reflected in a negative net worth.

\section{STOCHASTIC METHODS}

By and large, the deterministic methods can be regarded and used as a first (albeit crude) approximation for assessing fiscal sustainability. Also, they can serve as the basis for conducting stress tests or for examining the effect of alternative policy changes on fiscal sustainability. They are, however, limited by applying individual shocks to the baseline debt scenario and testing the sensitivity of the debt dynamics. By contrast, stochastic techniques help calculate a probability density function of the possible outcomes, including the probability of sovereign default, by simulating a very large number of random shocks.

Broadly stated, the stochastic approach seeks to assess fiscal sustainability explicitly under uncertainty. Although it remedies the limitations of the deterministic methods, they tend to be more costly in terms of analytical complexity and data requirements. This is the reason why stochastic methods have been developed by multiple authors and applied to relatively few countries. Here we review five methods for assessing risk-adjusted fiscal sustainability of possible application to emerging market economies in Asia. Existing applications to Asian economies are in fact highlighted in the narrative.

\section{Vector Autoregression and Value-at-Risk}

Two stochastic methods have been developed on the basis of two deterministic methods: one is the vector autoregressive (VAR) approach built on the standard DSA template and the other consists of the Value-at-Risk ( $\mathrm{VaR}$ ) analysis as an extension of the intertemporal balance-sheet approach to evaluating fiscal sustainability.

Based partly on earlier work by Ferrucci and Penalver (2003) and Garcia and Rigobon (2004), Celasun, Debrun, and Ostry (2006) sought to enhance the original DSA template by incorporating uncertainty in three steps. The first, the basis of stochastic simulations, calibrates a joint probability distribution of shocks to historical data for each of five emerging market economies (Argentina, Brazil, Mexico, South Africa, Turkey) with VAR estimates of the effects of the variance and covariance of growth, interest, and exchange rates, on public debt. In the second step, a fiscal policy reaction function is estimated between primary balances, past debt, and the output gap, on a heterogeneous cross-country sample-of questionable relevance for the five selected economies. The third step combines the estimates from the other two steps to generate stochastic simulations around a medium-term baseline projection of the debt ratio over a medium-term horizon. Monte Carlo simulations are performed to generate yearly frequency distributions of the debt ratio that can be illustrated with a three-dimensional fan chart, shown below. 
Figure 3: Southeast Asian Countries: VAR-Based Fan Charts, 2016-2020

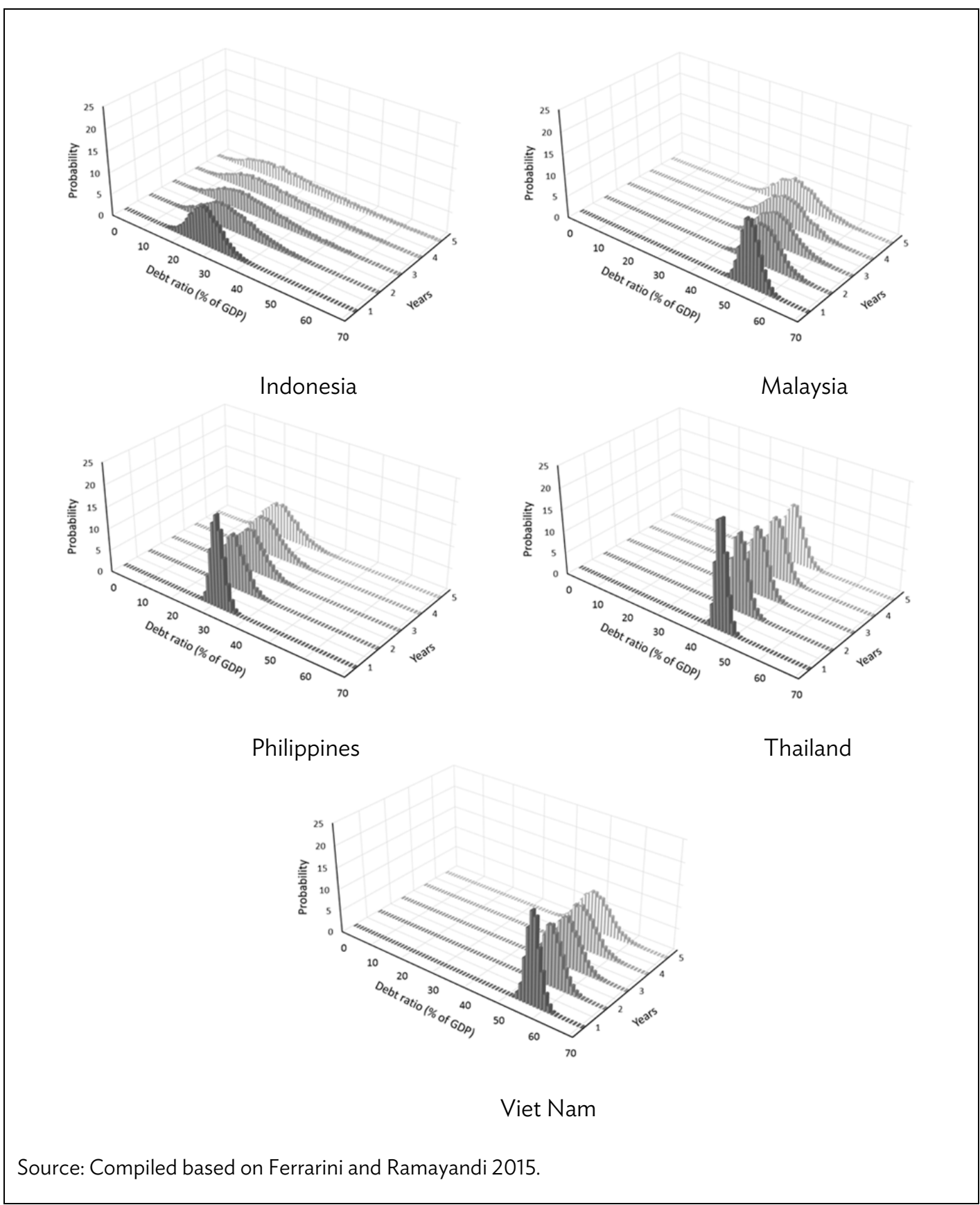

Frank and Ley (2008) refined the VAR-based estimates in several respects, with an application to three of the economies selected from the foregoing sample. One innovation was to identify and allow explicitly for structural breaks - typical especially in emerging market economies undergoing financial crisis episodes-departing from the stationarity assumption in the standard VAR estimation. Another improvement is the relaxation of the normality assumption in the probability of shocks, thereby permitting specification of asymmetric tails. In addition, instead of estimating the reaction function subject to data constraints-probably the weakest feature in the earlier application-the reaction function is posited in terms of a debt stabilizing primary balance. 
Ferrarini and Ramayandi (2012, 2015) applied the VAR-based method with some modifications. To deal with data limitations, they employ quarterly data to estimate the variancecovariance of GDP growth, inflation, interest, and exchange rates underlying the dynamics of the public debt ratio, and annualized them to produce fan charts with a 5-year probability distribution of the debt ratio for a diverse group of Asian economies (Georgia, India, Indonesia, the Republic of Korea, the PRC, the Philippines, Thailand, and Viet Nam). More recently, calculations were updated for the eight economies and expanded to include five additional Asian economies (Azerbaijan, the Kyrgyz Republic, Malaysia, Mongolia, and Sri Lanka). ${ }^{13}$ An advantage of these risk-adjusted debt sustainability exercises is that these economies exhibit differences in fiscal behavior and are exposed to risks stemming from a variety of different sources.

Since Ferrarini and Ramayandi (2015) stand alone in the application of the VAR approach in Asia, here we show the resulting three-dimensional fan charts for five economies in the region (Figure 3). The charts indicate that, as the time horizon of the projection lengthens, uncertainty increases and the probability density function becomes flatter, with larger fat tails. While the debt ratio baseline projections decline in most cases, a broad range of possible outcomes does not rule out higher than the baseline debt ratio during 2015-2020. In Indonesia, for example, under the recent volatility in macroeconomic conditions, the debt ratio may well increase quite substantially in the coming years.

Although the fan-chart analysis is useful to capture inaccuracies in macroeconomic assumptions underlying a debt sustainability analysis, it remains mute as regards probable risk factors that may affect a country's fiscal sustainability. This method can be interpreted as a large sample stress test to the path of future debt ratio, but it misses out possible additional shocks to the public sector balance sheet that may come from contingent risks, stemming for example from demographic trends. To account for such risks, one needs to incorporate appropriate methods of risk analysis into the analysis, as done in the methods outlined next.

Following up on a suggestion by Dornbusch (1998) in the context of the Asian financial crisis, Barnhill and Kopits (2003) adapted to the public sector the VaR method, for assessing the potential loss from an investment portfolio. The method, well known in the private finance sector, has been used to calculate the effect of macroeconomic volatility on each major category of assets and liabilitiesincluding the probability of realization of explicit and implicit contingent assets and liabilities-within a comprehensive intertemporal balance sheet of the public sector, expressed in present value terms. The worst potential outcome of stochastic shocks on fiscal sustainability is estimated at a given confidence level. Specifically, the shocks are subject to a very large number of draws, with Monte Carlo simulation computing the variance and covariance of the various sources of risk (output, price level, exchange rate, interest rates, risk premium, and oil price, among others). In the empirical part, the $\mathrm{VaR}$ was tested for Ecuador in the year 2000 when the country was hit by fiscal, banking, currency, and climatic crises. The baseline simulation of the effect of all shocks is shown with a probability density function for the net worth of the public sector, exhibiting a fat tail risk at a 5\% probability (Figure 4). Upon removing sequentially each source of risk, the distribution of outcomes becomes tighter around the mean and the tails become less prominent.

13 In yet another recent application to an Asian economy, Medina (2015) used a VAR technique to calculate stochastically a fan chart for Bangladesh. 
Figure 4: Ecuador: Value-at-Risk Public Sector Net Worth, 2000 (\$ billion)

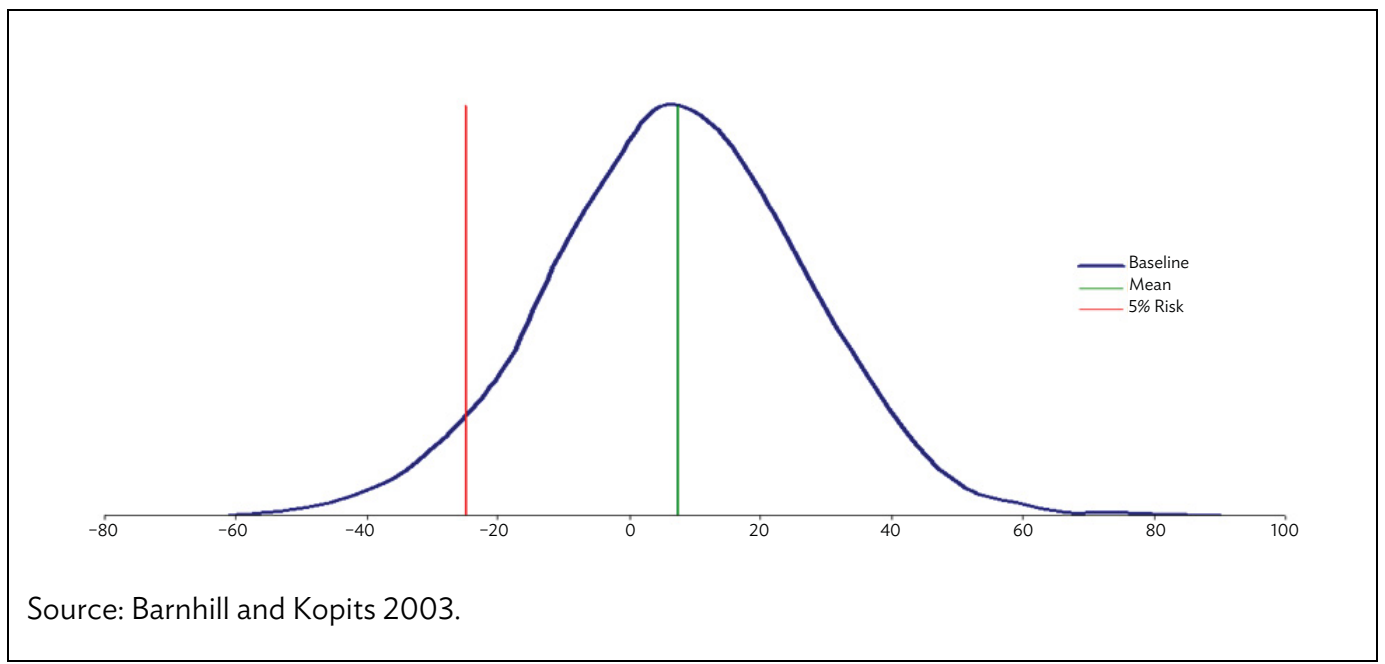

The $\mathrm{VaR}$ results for Ecuador have a potentially important political economy implication for policy makers in countries that are well endowed with natural resources and/or with foreign exchange reserves, including in the form of sovereign wealth funds. Frequently, in these countries, politicians invoke these resources as an insurance against financial crises and creditors see them as implicit collateral for lending, thereby underestimating sovereign risk. However, the case of Ecuador's VaR illustrates the danger of such moral hazard. While the deterministic intertemporal net worth of the public sector is positive, the risk-adjusted net worth is in the negative territory at a $35 \%$ probability.

In subsequent applications to Latin American economies, the $\mathrm{VaR}$ approach was adapted to government debt, without explicitly accounting for contingent liabilities. ${ }^{14}$ Da Costa et al. (2004) conducted VaR simulations in Brazil for 2001, 2002, and 2003, allowing yearly comparisons of riskadjusted public debt ratios, which permit assessing the evolution of vulnerability over time. Adrogue (2005) applied the $\mathrm{VaR}$ technique to compare public debt sustainability and fat-tail default risk facing Central American economies (Costa Rica, Dominican Republic, El Salvador, Guatemala, Honduras, Nicaragua, Panama) in 2008. Both studies are helpful for intertemporal and cross-country comparisons of fiscal risk, but without benefitting from a lesson in political economy derived from full $\mathrm{VaR}$ analysis of public sector intertemporal net worth.

In an application of $\mathrm{VaR}$ to the Indonesian public sector, the only one to an Asian economy, Barnhill et al. (2010) disaggregated the intertemporal balance sheet, with a near-complete coverage of contingent asset and liabilities. In an innovation over previous $\mathrm{VaR}$ analyses, they found that the results are sensitive to the period selected for computing the variance-covariance matrix of risk variables. For the tranquil period (2000-2006), Indonesia's sovereign net worth exhibits a much smaller fat-tail risk than for crisis periods (1997-1999 or 2007-2009).

14 As an exception, Budina and van Wijnbergen (2009) specified a highly stylized version of VaR analysis to the public sector in Turkey and calculated the fiscal adjustment required to stabilize the debt ratio following the 2001 crisis. 


\section{Contingent Claims Analysis and Fiscal Stress Index}

Although without addressing directly fiscal sustainability in terms of the likely trajectory of public debt or net worth, there are two stochastic methods that shed additional light on the vulnerability of the public sector to default risk. One is the contingent claims analysis (CCA) and the other is a lesser known fiscal stress index, both applied mainly to emerging market economies with a history of fiscal crises. Unlike the previous stochastic methods, neither of these methods builds on deterministic techniques.

CCA originates in the Merton models for option pricing (Merton 1973) and its application to the pricing of corporate debt (Merton 1974), while its application to sovereign risk is rooted in an attempt by Xu and Ghezzi (2003) at estimating the "fair spread" on sovereign bonds on the basis of macroeconomic fundamentals and the government balance sheet, in contrast to the spread observed in financial markets driven by volatile shifts in investor sentiment. The fair spread method is focused on calculating sovereign default probabilities which, through the term structure, are used to estimate a given country's fair spread. As initially formulated, default probabilities are driven primarily by the level of foreign exchange reserves, whereby default is approached, rather mechanically, upon exhaustion of the reserves. It was first applied to a handful of emerging market economies, and then replicated rather successfully for Brazil by da Costa et al. (2004).

The method has been further extended by Gray and Jones (2006); Gray, Merton, and Bodie (2007); Gapen et al. (2008), adapting CCA from the financial analysis of credit risk. A major advantage of the method is that it can be used to simulate systemic shocks across the sovereign, banking, and real sectors, drawing on balance-sheet and macroeconomic variables. The method's coverage extends beyond the public sector, with linkages to the rest of the economy through sectoral balance sheets. Various versions of CCA have been applied not only to a number of emerging market economies, but also to EU member countries and the United States.

CCA offers a solution to the main challenge facing RFSA, namely, that the market value of sovereign assets (except for liquid assets, such as official foreign exchange reserves) cannot usually be observed directly and thus requires estimation. The latter, however, would entail calculation of the present value of future flows, such as discounted primary balances. To circumvent arbitrary assumptions concerning cash flow projections, including the discount factor and future revenue flows, CCA is used to derive the implied value of sovereign assets - that is, "contingent claims"-from the values of liabilities, which are typically observed and their match with asset values is given by the balance sheet equality. Furthermore, it is assumed that liabilities have different priorities and that assets follow a stochastic process. Based on these principles, the CCA sovereign balance sheet is derived from the accounting balance sheet of the consolidated government and central bank.

Various country applications of CCA include two Asian economies, the Republic of Korea and the Philippines (Gray, Merton, and Bodie 2007), as well as a retrospective analysis of the Thai financial crisis of the 1990s (Gray and Malone 2008, 2012). The method allows for the application of the BlackScholes-Merton option price formulae to derive sovereign asset value and volatility from the observed value and volatility of sovereign liabilities. Against any given distress barrier, quantitative risk measures are then derived from the calibrated parameters of the CCA sovereign balance sheet, such as distance to distress and probabilities of default. Applied to emerging market countries, such as the Republic of

Korea and the Philippines in Figure 5, the CCA-based default probability closely resembles over time the market sentiment embodied in the 1-year sovereign credit default swap spreads. 
Figure 5: The Republic of Korea and the Philippines: Sovereign Default Probability and CDS Spreads, 2002-2004

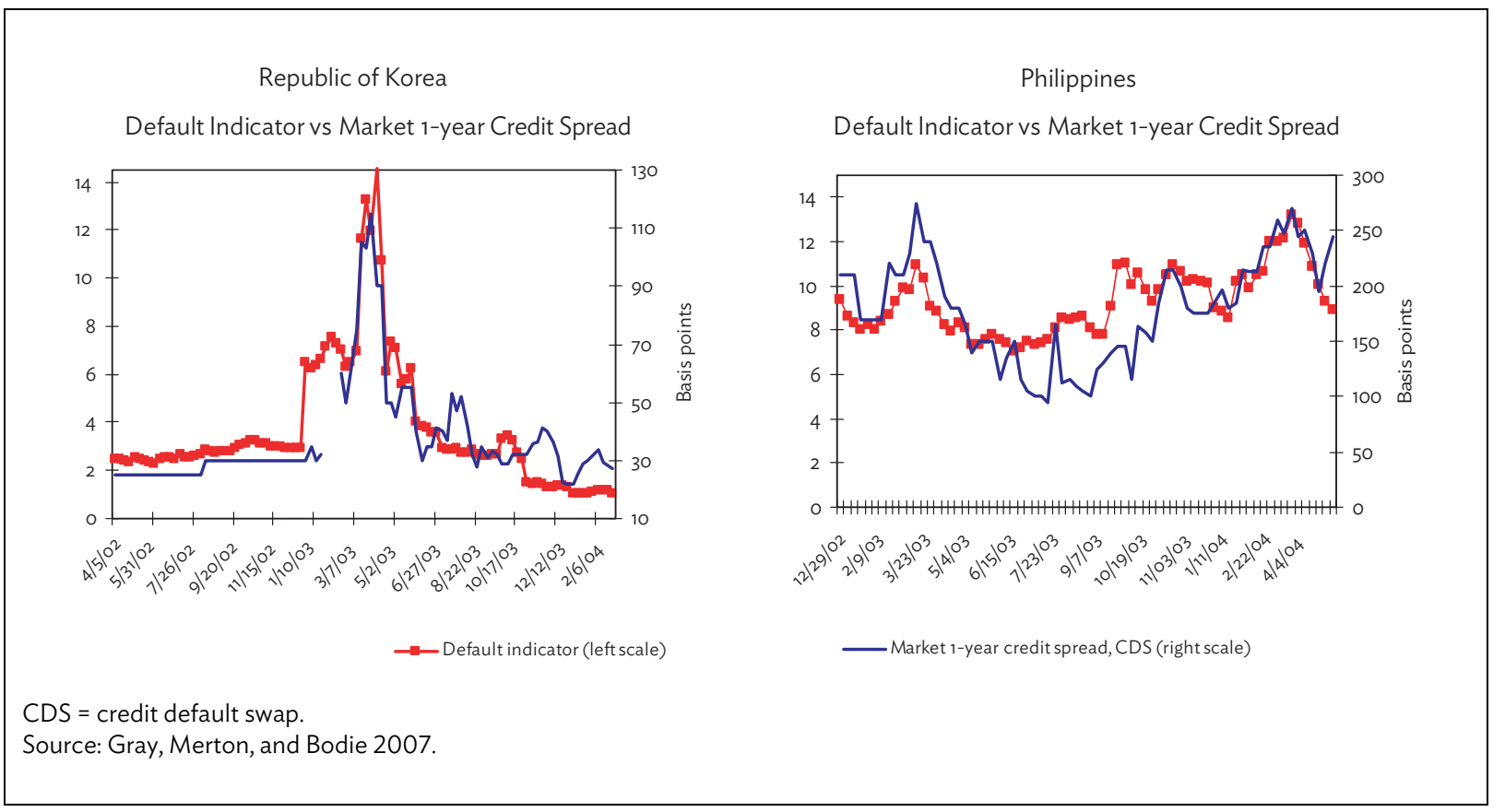

The relevance and applicability of the CCA framework derives mainly from its adaptability to reflect the interactions between the sovereign and other sectors of the economy, such as banks, nonfinancial corporations, and households. Gray and Malone (2012) describe how the government's risk exposure may derive from its provision of financial and asset guarantees to the finance sector or from its own equity stake in that sector. These risk exposures affect the value of government's assets and thus its own risk of default and cost of borrowing. This in turn may increase bank spreads, to the extent that investors see banks' and sovereign's risks as intertwined. Unless the government is able to provide the necessary guarantees to cover finance sector losses, this vicious cycle may lead to a financial and sovereign debt crisis.

All told, CCA is in essence an analytical tool for monitoring, through linked sectoral risk premiums, not only solvency, but also liquidity of the public sector. In the event, this is reflected in how well the estimated risk indicator tracks sovereign risk premium in financial markets - thereby departing from the original objective of estimating the "fair spread." CCA usefully identifies the market's current assessment of sovereign risk, and potentially, of correlated financial system risk levels. However, CCA has limited usefulness in the assessment of lower probability systemic events with high potential costs and of policies to deal with such contingencies. In other words, the question arises as to whether CCA is useful as a forward-looking measure of fiscal sustainability, based on fundamentals, or rather an analytical approach of intrinsic value but of limited usefulness for policy making, given the difficulty of disentangling the various risk variables that determine the synthetic risk indicator.

Borrowing from the methodology of early warning systems (EWS) for currency, banking, and debt crises, Baldacci et al. (2011) developed a fiscal stress index (FSI). ${ }^{15}$ The index rests on threshold

15 See Goldstein, Kaminsky, and Reinhart (2000) on banking and currency crises, and Manasee, Roubini, and Schimmelpfennig (2003) on sovereign debt crises. 
values that signal vulnerability to a fiscal crisis, on the basis of an arbitrary composite of 12 fiscal variables classified into three clusters (basic fiscal variables, long-term fiscal trends, and asset and liability management). The variables are selected depending on their past contribution to fiscal distress episodes for some 80 countries, estimated with logit regressions over the period 1995-2010. The index proves to be a useful device for discriminating among the selected variables in signalling fiscal stress in advanced economies as compared to emerging market economies, including during the recent financial crisis. However, as in the case of other EWS techniques, including those implemented by the Asian Development Bank for its member countries, the ultimate test of operational usefulness lies in correctly signalling country-specific fiscal vulnerability beyond the estimation period. ${ }^{16}$

\section{Macrofiscal Models}

Fully specified stochastic macroeconomic models, with a detailed fiscal block, are seen as the ideal way of capturing fiscal risk. Several attempts have been enlightening in this regard, their limited applicability across countries notwithstanding. Here we examine two such models.

Mendoza and Oviedo (2004, 2006) constructed structural and general equilibrium models, incorporating stochastic features, to explain the ability of governments in emerging market economies to borrow in international financial markets. The capacity to borrow is primarily determined by the high volatility of tax revenue-while implicitly excluding other sources of volatility-when compared to the case of advanced economies. This rather restrictive specification serves to set the natural limit to indebtedness, a constraint that the government is willing to meet with an adjustment in expenditures alone, subject to the political tolerance of the private sector. On the empirics, the cases of Brazil, Colombia, Costa Rica, and Mexico provide sufficient diversity as regards revenue volatility, vulnerability to debt crises, and propensity to adopt a fiscal stance to remedy the crisis.

The macroeconomic model developed by Kamenik et al. (2013) is the most recent stochastic approach at measuring fiscal risk, focused exclusively on three advanced economies (Austria, Czech Republic, and Germany). It essentially consists of a simple and flexible semistructural model modified with dynamic stochastic general equilibrium features, applied to historical data for each economy. The authors compare the actual public debt ratio with the target debt ratio implicit in the fiscal policy derived from the model over a decade, to assess the fiscal outlook facing each economy. In addition, a forward-looking fiscal stress test is conducted with projected probability distributions based on the model over 2 decades, incorporating fiscal reaction functions, to assess the risk of failure to comply with the debt rule. The results of the test are presented in fan charts showing uncertainty bands around baseline projections of key performance variables: government debt, overall budget balance, primary balance, and interest cost, all stated as a proportion of GDP.

\section{Summing Up}

Although still to be regarded in some ways as experimental at this stage, the foregoing stochastic methods offer insights and useful toolkits for a thorough and realistic evaluation of fiscal risks in fiscal sustainability analysis. Table 1 summarizes and compares the main features of the reviewed methods, with the exception of macrofiscal models. To a greater or lesser extent, they all face a major challenge in communicating the methodology and the results in clear and nontechnical terms-ranging from the VAR-based fan chart and FSI as the easiest to the CCA and VaR as the most difficult-to policy

16 See ADB (2005) for ADB's Early Warning System applied to East Asian economies. 
makers, legislators, the general public, and in some cases, even to financial markets. Failure to address this challenge may render any practical application a black box, only accessible to experts.

Table 1: Comparison of Stochastic Methods

\begin{tabular}{|c|c|c|c|c|}
\hline & $\begin{array}{c}\text { Vector } \\
\text { Autoregression }\end{array}$ & $\begin{array}{l}\text { Value- } \\
\text { at-Risk }\end{array}$ & $\begin{array}{c}\text { Contingent } \\
\text { Claims }\end{array}$ & $\begin{array}{c}\text { Fiscal Stress } \\
\text { Index }\end{array}$ \\
\hline \multicolumn{5}{|l|}{ Types of risks } \\
\hline Specific risks & & $x$ & & \\
\hline General risks & $x$ & $x$ & $x$ & $x$ \\
\hline Systemic risks & & $\mathrm{x}$ & $\mathrm{x}$ & \\
\hline \multicolumn{5}{|l|}{ Performance indicator } \\
\hline Public sector debt & $x$ & $x$ & & \\
\hline Public sector net worth & & $x$ & & \\
\hline Sovereign risk indicator & & & $x$ & $\mathrm{x}$ \\
\hline \multicolumn{5}{|l|}{ Timeframe of assessment } \\
\hline Ex ante & $x$ & $x$ & & $x$ \\
\hline Expost & & & $x$ & \\
\hline \multicolumn{5}{|l|}{ Focus of assessment } \\
\hline Stability & $x$ & & & \\
\hline Solvency & & $x$ & $x$ & \\
\hline Liquidity & & & $\mathrm{x}$ & $\mathrm{x}$ \\
\hline \multicolumn{5}{|l|}{ Specification } \\
\hline Structural & & $x$ & & \\
\hline Reduced form & $x$ & & $x$ & $x$ \\
\hline \multicolumn{5}{|l|}{ Identification } \\
\hline Sources of risk & $\mathrm{x}$ & $\mathrm{x}$ & & $\mathrm{x}$ \\
\hline Policy measures & & $\mathrm{x}$ & & \\
\hline \multicolumn{5}{|l|}{ Sectoral linkages } \\
\hline Yes & & $x$ & $x$ & \\
\hline No & $x$ & & & $x$ \\
\hline \multicolumn{5}{|l|}{ Data, software needs } \\
\hline High & & $\mathrm{x}$ & & \\
\hline Low & $x$ & & $x$ & $x$ \\
\hline \multicolumn{5}{|l|}{ Communication } \\
\hline High & $x$ & & & $x$ \\
\hline Low & & $\mathrm{x}$ & $\mathrm{x}$ & \\
\hline
\end{tabular}

Source: Authors' compilation.

Both VAR and $\mathrm{VaR}$ are forward-looking methods to assess fiscal sustainability under risk, but their predictive capacity cannot be verified. By contrast, CCA is its backward-looking focus insofar as its default risk indicator gauges and explains investor sentiment up to the present. FSI stands apart in that it can serve both perspectives. As a corollary, CCA and FSI indicators are intended to ascertain the risk of a sovereign crisis in terms of a "sudden stop" in liquidity, whereas VAR and VaR are geared to estimate medium- to long-term fiscal sustainability, in terms of stability and solvency, respectively.

On technical grounds, each method has some advantages vis-à-vis the others. Among them, the CCA, and VaR seem to be most amenable to operational application to the extent they are tailored to the environment of a given country. In this regard, the usefulness of VAR and FSI can be enhanced 
by shifting reliance from cross-country parameter estimates onto country-specific estimation and simulations. In particular, further refinement of the FSI in this direction might improve its reliability as a leading indicator of vulnerability to a sovereign crisis.

Macrofiscal models specified for evaluating fiscal risk are set in the context of a full-fledged theoretical framework, at the cost of being too specialized, restrictive, and less communicable. Yet a distinct advantage of these models is that, by their very nature, they allow for the endogeneity of shocks by transmitted between key macroeconomic variables. Therefore, they can be used to perform more realistic sensitivity analysis than ordinarily done by treating simulated shocks as exogenous. In particular, dynamic stochastic general equilibrium models are supposed to highlight explicitly stochastic behavioral relationships throughout the entire economy.

Among the methods reviewed, CCA and $\mathrm{VaR}$ methods can capture economywide systemic risks through intersectoral linkages in determining sovereign default risk. However, potentially, the $\mathrm{VaR}$ method is the most versatile in its coverage of fiscal risks and their impact on public sector net worth, rather than being focused on just public sector debt. Within a consistent analytical framework, it can incorporate model-based stochastic simulations of major macroeconomic and financial shocks. Beyond its usefulness in assessing general risks (including those associated with natural disasters, such as El Niño), it can also be employed to estimate the effect of specific risks associated with contingent liabilities, and to help assess systemic risks stemming from the finance sector. Thus the VaR approach, like recent extensions of the CCA, could trace negative feedback loops between the financial and the public sectors - of concern for policy makers. An additional benefit of the $\mathrm{VaR}$ analysis is that it can readily trace the impact of particular risk variables and of their interaction on the sovereign intertemporal balance sheet, whereas in practically all other methods risk variables are specified in reduced form. By the same token, it can identify the impact of specific policy measures or reforms on fiscal vulnerability. However, these advantages come at the comparably high costs $\mathrm{VaR}$ analysis entails in terms of data and computational requirements.

\section{ROAD MAP FOR APPLICATION TO ASIAN ECONOMIES}

The present section provides an outline of the practical steps that lie ahead in an actual application of a risk-adjusted fiscal sustainability analysis (RFSA) to selected Asian economies. It begins with country selection, followed by a review of the minimum data needs and availability to construct the scaffolding for the quantitative analysis. Next, it proceeds to a higher computational level, specifying additional requirements for a comprehensive RFSA.

As a first step, candidate economies are to be selected on the basis of two criteria. The first criterion is the vulnerability of the economy, and specifically, of the public sector to various types of risks. The latter can be determined in part by examining past and current experience, including history of currency, banking, and debt crises. Examples include reliance on primary commodity exports, exposure to financial shocks, to demographic risks, or to climate risks. Although an existing high debt ratio can be regarded as prima facie evidence of a sustainability problem as well as sensitivity to such risks, vulnerability is to be assessed in a forward-looking manner, taking into account future prospects especially in the light of implicit contingent liabilities. Appendix I describes a first, partial such attempt at categorizing Asian economies' risk profiles.

The second criterion for selecting a candidate economy consists of availability of key components of public sector balance sheet data. While actual data on public debt are indispensable 
for conducting even a rudimentary public DSA, there is need for additional categories of actual and prospective streams of assets and liabilities even if such information is available in fragmentary or estimated form. The coverage of the public sector must at least extend to the central budget and major extrabudgetary operations. But in certain economies with large subnational governments, coverage must extend to lower tier governments as well. By the same token, in the case of widespread government ownership and presence in the economy, it is necessary to create a consolidated public sector balance sheet including state-owned enterprises, both nonfinancial and financial. Such extensions are imperative where the source of vulnerability lies to a considerable extent outside the central government.

The foregoing sections of this paper suggest that among various attempts at introducing risk in FSA, the most promising avenue is through a comprehensive intertemporal balance sheet of the public sector. This is a major task even for an advanced economy, with sound public finances, let alone for an emerging market or a developing economy, with government statistics of questionable quality and coverage. It involves constructing first of all a balance sheet, with all assets and liabilities at market value, consolidated for the public sector as a whole, including the central bank and other official financial institutions.

As compared to the conventional balance sheet, expressed by the book value of the stock of actual assets and liabilities at a moment in time, the intertemporal balance sheet is an estimate of the market value of existing assets and liabilities, as well as of the present value of all future assets and liabilities, contracted in the past and to be contracted in the future. Thus the intertemporal balance sheet of the public sector incorporates the discounted future flows of government revenue and expenditures, including those associated with the projected realization of contingent assets and liabilities. In addition to the government, the balance sheet is consolidated with the state-owned enterprises and financial institutions. The meaning of the intertemporal balance sheet for the public sector of course differs from that of a business enterprise. For both entities the resulting net worth reflects solvency, assuming unchanged behavior or unchanged policies; that is, a negative value indicates the prospect of bankruptcy or default. However, if politically feasible, the public sector can undertake policy changes to avoid default.

As noted, the most thorough, transparent, and comprehensive intertemporal balance sheet is published annually by the UK Office for Budget Responsibility (2015), as part of its report on fiscal sustainability. The Office does not pretend precision in these calculations. In fact, it is stressed that it is subject to considerable uncertainty in terms of estimate and assumptions underlying the projections. Yet to date, this is the best exercise of its kind in terms of analysis and communication.

The UK report is pedagogically enlightening in that it provides a sequential overview of the building blocks of the estimates from the conventional to the intertemporal balance sheet of the public sector. Specifically, as a first step, it begins with simply general government gross debt, or the "National Accounts" public sector net debt, calculated as the difference between all accumulated liabilities less liquid financial assets. ${ }^{17}$ The second step consists of the ordinary measure of actual net worth, given by

17 Measuring public sector net debt requires a high degree of transparency insofar as it is open to manipulation-given the incentives under Goodhart's law. As demonstrated in Brazil and Japan, official statistics on public sector net debt includes significant nonmarketable financial and real assets owned directly or indirectly by the government. In order to avoid such manipulations, for monitoring compliance with the debt limit under the Stability and Growth Pact, EU member countries are required to report general government gross debt. Government-owned physical assets are particularly suspect insofar as they tend to be nonmarketable. For this reason, in Canada, public infrastructure, national monuments, national parks and the like are assigned a symbolic value of $\$ 1$. 
the difference between all actual assets and all liabilities. The third measure, called the "Whole of Government Accounts" includes, in addition, future liabilities incurred from past activities as well as contingent liabilities. As a final step, the exercise concludes a comprehensive intertemporal balance sheet by incorporating the present value of all additional future assets plus revenue flows, less future liabilities, to calculate the intertemporal net worth. Table 2 illustrates these steps broken down into past and future components. Estimation of nonmarketable assets plus future revenue and expenditure flows, beyond the first step, remains a particularly challenging task.

Table 2: Summary of the Intertemporal Balance Sheet of the Public Sector

\begin{tabular}{ll}
\hline \multicolumn{1}{c}{ Assets } & \multicolumn{1}{c}{ Liabilities } \\
\hline $\begin{array}{l}\text { Liquid assets (including foreign exchange } \\
\text { reserves, sovereign wealth funds) }\end{array}$ & Gross domestic liabilities \\
Illiquid assets & Gross foreign exchange liabilities \\
Physical assets & \\
& \\
Other future assets & Future liabilities incurred in the past \\
Future revenue inflows & Future liabilities incurred in the future \\
Contingent assets & Contingent liabilities \\
(explicit and implicit) & (explicit and implicit) \\
\hline
\end{tabular}

Source: Authors' compilation.

There are multiple ingredients for these calculations apart from estimates of the value of the existing stock of assets and liabilities. Future assets and tax revenue are projected on the basis of the tax system driven by assumptions about future productivity trends, including contingent assets and revenue from nonrenewable resources, with assumptions about the probability of exploitation of projected reserves. Future liabilities are projected on the basis of statutory obligations, such as public pension benefits and other social entitlements, subject to take-up rates from past contributions, derived from demographic and socioeconomic variables, and contractual terms applying to contingent claims, qualified by the probability of realization, stemming mainly from government guarantees, deposit insurance schemes, and public-private partnership programs. A critical input for the calculation of the present value of future assets and liabilities is the choice of an appropriate discount rate.

The intertemporal balance sheet is the most advanced tool for FSA, yet it can only be regarded as a baseline or central scenario. As such, it is useful for simulating the impact on fiscal sustainability of wellidentified changes or reforms in the fiscal area (especially in taxation, mandatory spending programs, fiscal policy rules); and of certain regulatory changes affecting the financial system (for example, deposit insurance); state-owned enterprise sector (for example, government guarantees) or subnational governments (for example, no-bailout provisions). However, it is limited insofar as it precludes any formal treatment of uncertainty and risk.

In order to relax the assumption of certainty in FSA, it is necessary to conduct an RFSA, by enhancing the intertemporal balance sheet with a stochastic approach. As we have seen in the previous section, this can be accomplished with an adaptation of the $\mathrm{VaR}$ analysis to the public sector. This 
innovation was applied for the first time to Ecuador's public sector, with a summary of the results in Table 3, showing the intertemporal balance sheet by major asset and liability category.

Table 3: Ecuador: Risk-Adjusted Balance Sheet of the Public Sector, 2000 (\$ billion)

\begin{tabular}{|c|c|c|c|c|c|}
\hline & $\begin{array}{l}\text { Present } \\
\text { Value } \\
\text { (Mean) }\end{array}$ & $\begin{array}{c}\text { Risk- } \\
\text { Adjusted } \\
\text { Value }\end{array}$ & & $\begin{array}{l}\text { Present } \\
\text { Value } \\
\text { (Mean) }\end{array}$ & $\begin{array}{c}\text { Risk- } \\
\text { Adjusted } \\
\text { Value }\end{array}$ \\
\hline Assets & \multicolumn{5}{|c|}{ Liabilities } \\
\hline Recorded assets & & & Recorded liabilities & & \\
\hline Forex reserves & 1.4 & 1.4 & Short-term liabilities & 0.6 & 0.8 \\
\hline Other current assets & 2.1 & 1.6 & External liabilities & 10.1 & 12.3 \\
\hline Fixed assets & 1.7 & 1.3 & Domestic liabilities & 3.7 & 5.0 \\
\hline Other assets & 0.1 & 0.1 & Deficit guarantees & 0.9 & 1.2 \\
\hline Contingent assets & & & Contingent liabilities & & \\
\hline Petroleum reserves & 33.4 & 15.0 & Natural disasters (Niño) & 2.1 & 2.7 \\
\hline Biodiversity & 2.4 & 1.3 & Deposit guarantee fund & 2.0 & 2.8 \\
\hline $\mathrm{CO}_{2}$ capture & 1.6 & 0.8 & Public pensions (IESS) & 15.6 & 26.0 \\
\hline State-owned firms & 4.4 & 1.5 & & & \\
\hline Total assets & 47.1 & 28.9 & Total liabilities & 35.1 & 50.3 \\
\hline \multirow[t]{2}{*}{ Residual primary balance } & -4.7 & -14.0 & $\begin{array}{l}\text { Net worth (before residual } \\
\text { balance) }\end{array}$ & 12.1 & -15.2 \\
\hline & & & Net worth (incl. balance) & 7.5 & -23.8 \\
\hline
\end{tabular}

$\mathrm{CO}_{2}=$ carbon dioxide, IESS = Instituto Ecuatoriano de Seguridad Social.

Source: Barnhill and Kopits 2003.

Application of $\mathrm{VaR}$ to the intertemporal balance sheet of the public sector imposes additional, but relatively simple, data requirements regarding risk variables relevant to the selected economy. Risk variables may include interest rate spreads on government paper, exchange rate, market price of primary commodities, equity yields, and output, depending on the shocks to which the economy has been (or is likely to be) exposed. These variables are then to be incorporated into the analysis determined randomly or determined in terms of a specified function. For example, commodity prices may be assumed as following a random walk or may be generated by an estimated model.

Having selected the risk variables, the final step is to compute the variance and covariance matrix of their occurrence and the stochastic distribution of each major component of the intertemporal balance sheet around its mean present value. On this basis, we can calculate the intertemporal risk-adjusted net worth of the public sector (shown in Table 3), or stated otherwise, the fat-tail risk faced by the government, at a given (say, at $5 \%$ ) probability. As in the case of the earlier FSA, the RFSA can be also limited-on grounds of analytical convenience, limited data availability, or prudential considerations - to a subset of the balance sheet, for example by excluding some (or all) implicit contingent assets and liabilities.

As an ambitious extension, the $\mathrm{VaR}$ could be enriched within a broader real-world context that would allow capturing financial systemic risks in the FSA. This could be accomplished by adding 
linkages between the public sector and the finance sector, from where shocks originate through both explicit and implicit contingent liabilities. To this effect, it would be necessary to consider choosing between two approaches.

Under one such approach, the VaR would seek to integrate systemic risk modeling for major banking institutions and the government. The model would simultaneously assess the vulnerability of these banks and the government and gauge correlated bank solvency and liquidity risks, including those reflected in the interbank and sovereign markets. As part of the systemic risk assessment, correlated credit defaults among various groups of individual and corporate borrowers, as well as the government could be undertaken. The approach would draw on methodology developed by Barnhill and Souto (2009) and Barnhill and Schumacher (2011) to estimate correlated systemic solvency and liquidity risks for a banking system. Significant financial systemic risk factors include financial and economic environment regime shifts to stressful conditions, poor initial loan credit quality, loan portfolio sector and regional concentrations, bank depositors' sensitivity to uncertainty, and capital inadequacy. As a corollary, the methodology has the capacity to assess policy responses for moderating risk with such measures such as increased bank capital level, diversification of bank lending, reduction in volatility in the financial and economic environment, or reduction in sovereign risk through fiscal policy measures.

An alternative approach would involve a consolidated risk-adjusted balance sheet that would include banks and other financial institutions, as formulated in the CCA framework (Table 4). However, it remains to be explored whether consistency can be established between the intertemporal balance sheet and the CCA-based risk-adjusted balance sheet. In the latter, contingent liabilities in the form of guarantees are subtracted from the assets side, which consist of international reserves and other assets, net of guarantees. On the liabilities side, foreign currency debt is ascribed senior status over base money and local currency debt, which are collapsed and expressed in foreign currency terms. Sovereign default occurs when asset value falls below the payments due on foreign debt, constituting a distress barrier. The value of sovereign debt is risky because repayment hinges on the value and volatility of assets. Lending to sovereigns thus consists of an implicit guarantee equal to the expected loss of default. The contingent claim thus relates to holders of risky debt being short and the sovereign being long an implicit put option equal to the expected loss of default. By the same token, base money and local-currency liabilities are modelled as call options on the sovereign assets (Gray, Merton, and Bodie 2007).

Table 4: CCA-Based Sovereign Risk-Adjusted Balance Sheet

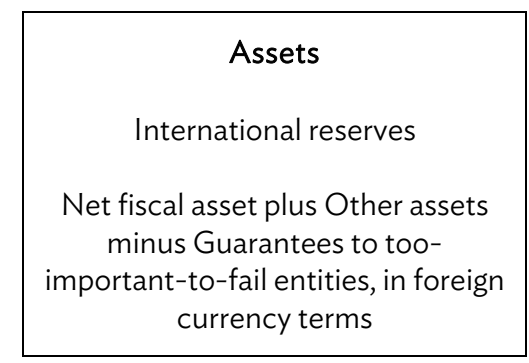

$\mathrm{CCA}=$ contingent claims analysis. Source: Gray, Merton, and Bodie 2007.

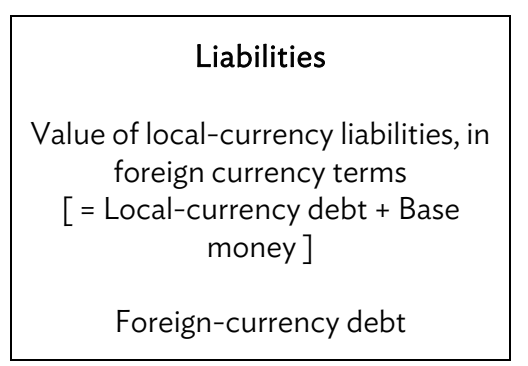

Foreign-currency debt 


\section{SUMMARY AND CONCLUSION}

Against the backdrop of past financial and fiscal crises, as well as the current primary commodity cycle and financial turbulence in Asia and elsewhere, this paper explores the analytical tools available for gauging fiscal sustainability under uncertainty. The objective, of course, is to help national authorities in managing and mitigating fiscal vulnerability in the region.

Our assessment of the pros and cons of methods of DSA suggests that, in general, both deterministic and stochastic approaches deserve a place in the practitioner's toolbox. The former is epitomized by DSA analysis in IMF Article IV consultations, as well as in the work of the World Bank, the Asian Development Bank, and other regional development institutions. Data parsimony and communicability being two clear advantages of the standard DSA template, its applicability extends to a broad range of economies. Its many applications span from tracing public debt ratios to scenario analysis and baseline forecasts, subject to stress tests reflecting alternative macroeconomic and fiscal projections, or under different policy assumptions. In a departure from the standard approach, a deterministic fiscal sustainability method has been developed in the context of an intertemporal balance sheet of the public sector, to calculate its net worth in present value terms. This method has been applied to a handful of advanced and emerging market economies, and it is found in an annual publication for the UK. Clear, actionable policy implications derived from such analysis, relating cause with effect, can be appealing to policy makers.

Limitations of the deterministic approach to assess fiscal sustainability lie in its focus on stabilizing the aggregate debt ratio or tracing its evolution over time, without quantifying the probability of macrofiscal risks. Moreover, sustainability benchmarks against which to assess the trajectory of the debt ratio are largely indeterminate. Further, the approach does not reflect the volatility and correlation among the macroeconomic drivers of debt dynamics, nor does it account for public assets, except in the intertemporal balance sheet method.

In contrast to deterministic methods, the stochastic approach seeks to assess fiscal sustainability explicitly under uncertainty. Admittedly, all stochastic methods are constrained in that, to a greater or lesser extent, underlying risk variables are largely generated from historical experience. Among various stochastic methods of risk-adjusted fiscal sustainability analysis (RFSA), four methods stand out in our review: vector autoregression (VAR), Value-at-Risk (VaR), contingent claims analysis (CCA), and fiscal risk index (FSI).

The VAR technique incorporates uncertainty into the standard DSA framework through its reliance on probability density functions over a wide range of possible outcomes, on the basis of autoregressive estimates of past fiscal behavior. Such large sample stress tests to the path of the future debt ratio significantly improve upon deterministic scenario analysis, but the approach remains mute as regards probable risk factors that may affect a country's fiscal sustainability. These are captured, however, by $\mathrm{VaR}$ and $\mathrm{CCA}$ methods.

VaR analysis computes the potential loss from an investment portfolio. Applied to a comprehensive intertemporal balance sheet of the public sector, it calculates the effect of macroeconomic volatility on each major category of assets and liabilities, and estimates at a given confidence level the worst potential outcome (fat-tail risk) for fiscal sustainability. VaR thus rests on the identification of all the line items in the sovereign's balance sheet, including contingent assets and liabilities, and their valuation in present value terms. But the market value of sovereign assets is not always directly observable and may have to be estimated, including on the basis of additional modeling. 
CCA seeks to circumvent the asset valuation problem by determining the value of public assets from the observable information on the liability side of the sovereign balance sheet. In this application to the public sector of the Merton model for firms, liabilities are considered as contingent claims on assets and are used to estimate their implied value. CCA usefully tracks market sentiment concerning sovereign risk and it can be used to simulate systemic shocks across the sovereign, banking and real sectors. Its shortcomings derive from its abstraction from asset valuation, possible defaulttriggering changes to which are thus beyond the scope of analysis. More important, the difficulty of disentangling the various risk variables that determine the CCA risk indicators, such as distance to distress, limits the method's relevance for policy making. In all, from a policy perspective, VaR seems to be the most versatile and useful method of RFSA, but can be very resource intensive in terms of informational and computational requirements.

The stochastic approach corrects the limitations of deterministic analysis at the cost of analytical complexity and significant data requirements. This applies in particular to $\mathrm{VaR}$ analysis and its informational and computational requirements of a comprehensive intertemporal balance sheet, and in particular the valuation of sovereign assets. Although estimates of such balance sheet for the public sector are available for a number of countries (Colombia, Ecuador, Greece, Indonesia, and Venezuela, in addition to several major advanced economies), application of the $\mathrm{VaR}$ method on such estimates has been limited so far to very few countries. Among developing countries, Ecuador stands out as having been subject to the first full-fledged $V a R$ analysis of the public sector. Indonesia is the only known Asian country study available, though not yet available in published form. Due to lesser demand for information, CCA has been applied more widely, mainly to advanced European economies, but also to some emerging market economies, including in Asia.

Drawing on our comparative survey of RFSA methods, we formulate a road map for possible implementation in Asian economies. As a first step, the road map calls for construction of a comprehensive balance sheet for the public sector-as done for the above mentioned countriesbeginning with the recorded liabilities of the general government, and then incorporating contingent liabilities and broadening the institutional coverage to the rest of the public sector. Assets, especially contingent assets, are to be entered at market value or possibly by applying the CCA valuation technique. In the last step, each major component of the balance sheet is subject to the VaR method for quantifying RSFA. Eventually, in an ambitious undertaking, the calculations could be expanded to the entire economy, with linkages to the finance and real sectors of the economy, and across major economies in the region in order to more fully capture systemic risks as well.

Ultimately, the usefulness to policy makers of the foregoing road map for the application of a stochastic approach-whether full or partial-to one or several Asian emerging market economies hinges on its capacity to identify the sources and extent of the risks in assessing fiscal sustainability. Moreover, policy makers should be able to ascertain, by comparing different time cuts, whether the public sector intertemporal net worth has improved or deteriorated over time. As well, policy makers should be able to simulate the impact of a hypothetical corrective action on the baseline trajectory of debt or net worth and on its stochastic distribution, including fat-tail risks of default.

In order to maintain or restore fiscal sustainability, an RFSA should help focus the conduct of fiscal policy over a medium-term to long-term horizon, with a view to formulating structural reform measures in the familiar areas of taxation, pensions, and other social entitlements, subnational government finances, state-owned enterprises, and other off-budget operations. Beyond public finances, it may be necessary to limit the perimeter of government guarantees (deposit insurance, public-private partnerships, etc.) and to minimize or eliminate implicit contingent liabilities (especially 
through an iron-clad no-bailout clause with respect to subnational governments, state-owned enterprises, and financial institutions) that may give rise to moral hazard. Such an effort must be paralleled with the strengthening of banking supervision and macroprudential regulation.

Additionally in the fiscal policy realm, a severe fiscal sustainability problem and high risk stemming from endogenous sources, such as time inconsistency, common pool problem, perennial deficit bias, and procyclicality, may require adoption of a rules-based fiscal framework that includes high transparency standards, all possibly under the surveillance of an independent fiscal watchdog to be put in charge, among other tasks, of producing official macrofiscal forecasts. ${ }^{18}$ On balance, experience with such frameworks in both advanced economies as well emerging market economies has been favorable.

Fiscal vulnerability to exogenous shocks (deterioration in the terms trade, decline in demand for exports, turbulence in financial markets, natural disasters) are largely outside the reach of policy and needs to be confronted with additional tools. These include adoption of various hedging devices, pricing guarantees, mandatory insurance, and adequate level of reserves in demographic and stabilization funds. ${ }^{19}$

18 See the discussion of the key elements of such a framework in Kopits (2012).

19 The effectiveness of a wide range of measures designed and implemented for the management and mitigation fiscal risks has been uneven across countries, as reported in Kopits (2014) on the basis of the recent Organisation for Economic Cooperation and Development Survey of Fiscal Risks. 


\section{APPENDIX: Developing Asia-Classification of Fiscal Risk, 2015}

This appendix contains the information underlying Figure 1 in the text body. Table A1 tabulates the indicators informing our assessment of risk factors facing the economies in developing Asia. Countryspecific risk factors were evinced mainly from the latest IMF article IV document available (Table A2 indicates the date of issuance), particularly in relation to data that are not otherwise accessible from other databases.

In Table A1, the Macroeconomic Vulnerability category concerns economies' outlook in terms of GDP growth, inflation, changes to the exchange rate, the primary balance, as well as the public debt ratio and the presence of subnational government debt.

Structural Risks capture vulnerabilities in relation to economies' total external debt position, its reliance on primary commodity exports, and the degree of exposure to natural disasters.

Contingent Risks assess the vulnerability of the banking sector, the level of household debt, and the weight of state-owned enterprises in the economy.

The intensity of these concerns are classified as High (H), Moderate (M), and Low or absent (L), according to the following criteria:

1. GDP growth: $H$, if average GDP growth in the last 5 years of observation was substantially lower compared to the previous decade and is currently projected to decline further; $M$, if average GDP growth in the last 5 years of observation was substantially lower compared to the previous decade but has turned around and is projected to increase, but is more volatile; $L$, if there is currently no expectation for GDP growth to decline.

2. Inflation: $\mathrm{H}$, if inflation is high (substantially higher during the past 5 years compared to the previous 10 years) and projected to stay high; $M$, if inflation is moderately high and also volatile; $L$, if inflation is low and stable.

3. Exchange rate: $\mathrm{H}$, if the currency has been depreciating markedly and that trend has not yet bottomed out; $M$, if exchange rate volatility is higher than during the last 5 years; $L$, if the exchange rate was relatively stable during the past 5 years.

4. Primary balance (\% of GDP): $\mathrm{H}$, if a large primary fiscal deficit is projected; $M$, if the projected deficits are mild and stable; $L$, if a surplus is expected, or a small deficit but with the prospect of further improvements.

5. Public debt (\% of GDP): $\mathrm{H}$, if public debt exceeds $60 \%$ of GDP; $M$, if public debt falls between 40 and $60 \%$ of GDP, or is slightly below $40 \%$ but on an increasing trend; $L$, if the public debt ratio is below $40 \%$ and expected to decrease further.

6. Subnational debt (fiscal fragmentation): $M$, if fiscal decentralization is pronounced and raises sustainability concerns; L, in the case of low fiscal decentralization is limited or absent (data for this indicator are hard to come by and we rely on available country regulation and documentation). 
7. External debt (\% of GDP), reliant on IMF Art IV External DSA results: $\mathrm{H}$, if external debt is $45 \%$ of GDP or higher; $M$, if the external debt ratio is close to $30 \%$ and up to $45 \%$ of GDP; $L$, if external debt is substantially below $30 \%$ of GDP.

8. Primary commodity exports (\% of GDP): $\mathrm{H}$, if the share of primary exports exceeds $15 \%$ of GDP; $M$, if this share is between $10 \%-15 \%$; $L$, if the share is less than $10 \%$.

9. Natural disasters, reliant on the World Risk Index 2014 (WRI) and the Global Climate Risk Index 1994-2013 (GCRI): H, if the economy ranks within the top 20 in either WRI or GCRI; M, if it ranks between 21 and 50 in either WRI or GCRI; L, if it ranks below the top 50 in either WRI or GCRI. (Note that Maldives is not listed in WRI and is ranked low in GCRI; yet we assigned it a high ranking because of its challenges being a low-lying atoll nation.)

10. Financial system vulnerability risk: based on the latest IMF Article IV assessment (see Table A2.)

11. Large SOEs: based on the assessments in the latest IMF Article IV and the World Bank Public Expenditure Review.

12. Demographic risk: $\mathrm{H}$, if the share of population aged 65 years or higher is projected to reach at least $20 \%$ by 2025 and $30 \%$ by 2050 ; $M$, if this population group is projected to reach $10 \%-$ $20 \%$ by 2025 and $20 \%-30 \%$ by 2050 ; L, if this population group is projected to fall below $10 \%$ by 2025 and below $20 \%$ by 2050 . 
Table A.1: Risk Matrix and Data Availability ${ }^{1 /}$

\begin{tabular}{|c|c|c|c|c|c|c|c|c|c|c|c|c|c|}
\hline \multirow[b]{2}{*}{ Economy } & \multicolumn{6}{|c|}{ Macroeconomic Vulnerability } & \multicolumn{3}{|c|}{ Structural Risks } & \multicolumn{3}{|c|}{ Contingent Risks } & \multirow{2}{*}{$\begin{array}{c}\begin{array}{c}\text { Demographic } \\
\text { Risks }\end{array} \\
\\
\text { Aging } \\
\text { population* }\end{array}$} \\
\hline & $\begin{array}{l}\text { GDP } \\
\text { growth } \\
\text { rate }^{*}\end{array}$ & $\begin{array}{c}\text { Inflation } \\
\text { rate }^{*}\end{array}$ & $\begin{array}{c}\text { Exchange } \\
\text { rate }^{*}(\text { LCU } \\
\text { per } \$)\end{array}$ & $\begin{array}{l}\text { Primary } \\
\text { balance* }\end{array}$ & $\begin{array}{c}\text { Public } \\
\text { debt }^{*} \% \\
\text { to GDP, } \\
2014)\end{array}$ & $\begin{array}{c}\text { Local } \\
\text { autonomy/ } \\
\text { Fiscal } \\
\text { decentrali- } \\
\text { zation }\end{array}$ & $\begin{array}{c}\text { External } \\
\text { debt* }\left(\% \text { to }^{*}\right. \\
\text { GDP, } \\
2014)\end{array}$ & $\begin{array}{c}\text { Primary } \\
\text { commodity } \\
\text { exports* }(\% \\
\text { to total } \\
\text { exports) }\end{array}$ & $\begin{array}{c}\text { Natural } \\
\text { disaster } \\
\text { (World Risk } \\
\text { Index and } \\
\text { Global } \\
\text { Climate Risk } \\
\text { Index })\end{array}$ & $\begin{array}{c}\text { Banking } \\
\text { sector } \\
\text { vulnerability* }\end{array}$ & $\begin{array}{c}\text { Household } \\
\text { debt }^{*}\end{array}$ & $\begin{array}{l}\text { Large state- } \\
\text { owned } \\
\text { enterprises }\end{array}$ & \\
\hline \multicolumn{14}{|l|}{ Central Asia } \\
\hline Armenia & M & M & $\mathrm{H}$ & $\mathrm{H}$ & $\mathrm{H}$ & M & $\mathrm{H}$ & M & L & L & L & $\ldots$ & M \\
\hline Azerbaijan & M & M & $\mathrm{H}$ & L & L & M & L & $\mathrm{H}$ & L & M & L & M & L \\
\hline Georgia & L & M & $\mathrm{H}$ & $\mathrm{H}$ & $M$ & M & $\mathrm{H}$ & M & L & $\mathrm{L}$ & L & $\ldots$ & $M$ \\
\hline Kazakhstan & M & M & $\mathrm{H}$ & $\mathrm{H}$ & L & M & $\mathrm{H}$ & $\mathrm{H}$ & L & $M$ & L & $\ddot{M}$ & $\mathrm{~L}$ \\
\hline Kyrgyz Republic & L & M & $\mathrm{H}$ & $\mathrm{H}$ & $M$ & $M$ & $\mathrm{H}$ & $\mathrm{L}$ & $M$ & M & L & $\ldots$ & L \\
\hline Tajikistan & $M$ & $\mathrm{~L}$ & $\mathrm{H}$ & $\mathrm{H}$ & $\mathrm{L}$ & $\mathrm{L}$ & M & $\mathrm{H}$ & M & M & L & $\ddot{H}$ & L \\
\hline Uzbekistan & $\mathrm{H}$ & M & $\mathrm{H}$ & L & L & M & L & M & M & L & L & M & L \\
\hline \multicolumn{14}{|l|}{ East Asia } \\
\hline People's Rep. of China & M & M & L & $\mathrm{H}$ & $\mathrm{H}$ & M & L & L & M & $\mathrm{H}$ & L & H & M \\
\hline Hong Kong, China & L & $\mathrm{L}$ & L & L & L & L & M & L & L & L & L & $\ldots$ & M \\
\hline Rep. of Korea & L & L & L & L & L & M & M & L & L & M & M & $\ldots$ & $\mathrm{H}$ \\
\hline Mongolia & L & M & $\mathrm{H}$ & $\mathrm{H}$ & $\mathrm{H}$ & L & $\mathrm{H}$ & $\mathrm{H}$ & M & M & $\mathrm{L}$ & $\ldots$ & L \\
\hline \multicolumn{14}{|l|}{ South Asia } \\
\hline Afghanistan & L & L & L & M & L & $M$ & L & L & $\mathrm{H}$ & M & L & $M$ & L \\
\hline Bangladesh & L & $\mathrm{H}$ & $\mathrm{H}$ & $\mathrm{H}$ & M & M & L & L & $\mathrm{H}$ & M & L & M & L \\
\hline Bhutan & L & L & $\mathrm{H}$ & L & $\mathrm{H}$ & $M$ & $\mathrm{H}$ & $\mathrm{H}$ & L & $\mathrm{L}$ & $M$ & $\ldots$ & L \\
\hline India & L & L & $M$ & $\mathrm{H}$ & $\mathrm{H}$ & $M$ & L & L & $\mathrm{H}$ & $\mathrm{H}$ & $\mathrm{L}$ & $\mathrm{H}$ & L \\
\hline Maldives & $M$ & $M$ & $\mathrm{~L}$ & $\mathrm{H}$ & $\mathrm{H}$ & L & $M$ & $M$ & $\mathrm{H}$ & L & L & $\ldots$ & L \\
\hline Nepal & L & $\mathrm{L}$ & $M$ & L & L & $M$ & L & $\mathrm{L}$ & $\mathrm{H}$ & $M$ & L & $\ldots$ & L \\
\hline Pakistan & L & L & $\mathrm{L}$ & L & $\mathrm{H}$ & M & L & L & $\mathrm{H}$ & $\mathrm{L}$ & L & $M$ & L \\
\hline Sri Lanka & L & L & M & $\mathrm{H}$ & $\mathrm{H}$ & $M$ & $M$ & L & L & L & L & $\ldots$ & M \\
\hline \multicolumn{14}{|l|}{ Southeast Asia } \\
\hline Cambodia & L & L & L & $\mathrm{H}$ & L & L & M & L & $\mathrm{H}$ & M & L & $\ldots$ & L \\
\hline Indonesia & L & L & $M$ & M & L & $M$ & L & $M$ & $M$ & $\mathrm{~L}$ & L & $M$ & L \\
\hline Lao People's Dem. Rep. & L & M & L & $\mathrm{H}$ & $\mathrm{H}$ & L & $\mathrm{H}$ & M & L & M & L & $\ldots$ & L \\
\hline Malaysia & L & $\mathrm{L}$ & M & M & M & L & $\mathrm{H}$ & $\mathrm{H}$ & $\mathrm{L}$ & $\mathrm{L}$ & M & $\ldots$ & L \\
\hline Myanmar & L & $M$ & $M$ & $\mathrm{H}$ & $M$ & L & L & L & $\mathrm{H}$ & $M$ & $\mathrm{~L}$ & $\ldots$ & L \\
\hline Philippines & L & $\mathrm{L}$ & $\mathrm{L}$ & L & L & $M$ & L & L & $\mathrm{H}$ & $\mathrm{L}$ & L & $\ldots$ & L \\
\hline Singapore & M & L & L & L & $\mathrm{H}$ & L & M & L & L & L & M & $\ldots$ & $\mathrm{H}$ \\
\hline Thailand & M & L & L & L & M & M & M & $\mathrm{H}$ & $\mathrm{H}$ & L & M & M & M \\
\hline Viet Nam & L & M & L & $\mathrm{H}$ & M & M & M & $\mathrm{H}$ & $\mathrm{H}$ & $\mathrm{H}$ & L & M & $\mathrm{L}$ \\
\hline \multicolumn{14}{|l|}{ The Pacific } \\
\hline Fiji & L & L & L & L & M & L & L & $\mathrm{H}$ & $\mathrm{H}$ & L & L & M & L \\
\hline Papua New Guinea & M & M & $M$ & $\mathrm{H}$ & $M$ & L & $\mathrm{H}$ & $\mathrm{H}$ & $\mathrm{H}$ & $\mathrm{L}$ & $\mathrm{L}$ & $M$ & L \\
\hline
\end{tabular}

$G D P=$ gross domestic product, $H=$ high concern, $L=$ low concern or absent, $L C U=$ local currency unit, $M=$ moderate concern

Notes: ${ }^{*}=$ data is readily available; $\ldots=$ data is limited; $1 /=$ list of data sources are in Table A3; data as of 16 October 2015.

Source: Authors' compilation. 
Table A.2: Source of Contingent Risks Classification

\begin{tabular}{|c|c|c|c|}
\hline Economy & $\begin{array}{l}\text { IMF Article IV } \\
\text { Release Date }\end{array}$ & Economy & $\begin{array}{l}\text { IMF Article IV } \\
\text { Release Date }\end{array}$ \\
\hline Central Asia & & Southeast Asia & \\
\hline Armenia & Mar-2015 & Cambodia & Feb-2014 \\
\hline Azerbaijan & Jun-2014 & Indonesia & Mar-2015 \\
\hline Georgia & Jan-2015 & Lao People’s Dem. Rep. & Feb-2015 \\
\hline Kazakhstan & Aug-2014 & Malaysia & Mar-2015 \\
\hline Kyrgyz Republic & May-2015 & Myanmar & Sep-2015 \\
\hline Tajikistan & Jun-2015 & Philippines & Aug-2014 \\
\hline \multirow[t]{2}{*}{ Uzbekistan } & Sep-2015 & Singapore & Jul-2015 \\
\hline & & Thailand & May-2015 \\
\hline East Asia & & Viet Nam & Oct-2014 \\
\hline People's Rep. of China & Jul-2014 & & \\
\hline Hong Kong, China & May-2014 & The Pacific & \\
\hline Rep. of Korea & May-2015 & Fiji & Nov-2014 \\
\hline Mongolia & Apr-2015 & Papua New Guinea & Jul-2014 \\
\hline \multicolumn{4}{|l|}{ South Asia } \\
\hline Afghanistan & May-2015 & & \\
\hline Bangladesh & Jun-2014 & & \\
\hline Bhutan & Jul-2014 & & \\
\hline India & Mar-2015 & & \\
\hline Maldives & Mar-2015 & & \\
\hline Nepal & Jul-2014 & & \\
\hline Pakistan & Apr-2015 & & \\
\hline Sri Lanka & Sep-2014 & & \\
\hline
\end{tabular}

$I M F=$ International Monetary Fund. Source: Authors' compilation. 


\section{Table A.3: Data Sources of Risk Variables}

\begin{tabular}{|c|c|c|c|c|}
\hline & Risks & Indicators & Source & Website \\
\hline 1 & Key macro variables & GDP, inflation, interest rates & ADO; IFS and WEO through Haver, CEIC & http://www.adb.org/publications/books \\
\hline \multirow{4}{*}{2} & \multirow{4}{*}{$\begin{array}{l}\text { External debt and } \\
\text { commodity exports }\end{array}$} & External debt (\% of GDP) & WDI through Haver; IMF Art. IV & http://www.imf.org/external/np/sec/aiv/index.aspx \\
\hline & & $\begin{array}{l}\text { Primary commodity exports } \\
\text { (breakdown by commodity) }\end{array}$ & OEC & http://atlas.media.mit.edu/en/profile/country/gbr/ \\
\hline & & $\begin{array}{l}\text { Primary commodity exports (\% to } \\
\text { total) }\end{array}$ & UN Comtrade; IFS through Haver, CEIC & http://comtrade.un.org/db/default.aspx \\
\hline & & $\begin{array}{l}\text { Primary commodity price indices and } \\
\text { futures }\end{array}$ & IMF & http://www.imf.org/external/np/res/commod/index.aspx \\
\hline \multirow{5}{*}{3} & \multirow{5}{*}{$\begin{array}{l}\text { Financial system } \\
\text { vulnerability }\end{array}$} & Financial Soundness Indicators-IMF & IMF & $\begin{array}{l}\text { http://data.imf.org/?sk=9F855EAE-C765-405E-9C9A- } \\
\text { A9DC2C1FEE47 }\end{array}$ \\
\hline & & $\begin{array}{l}\text { Global Financial Development } \\
\text { Database }\end{array}$ & WB & $\begin{array}{l}\text { http://econ.worldbank.org/WBSITE/EXTERNAL/EXTDEC/EXTGLOB } \\
\text { ALFINREPORT/0, ,contentMDK:23269602 pagePK:64168182 piPK: } \\
\text { 64168060 theSitePK:8816097,00.html }\end{array}$ \\
\hline & & Domestic credit to private sector & WB & http://data.worldbank.org/indicator/FS.AST.PRVT.GD.ZS \\
\hline & & $\begin{array}{l}\text { Aggregated commercial banks' } \\
\text { balance sheets }\end{array}$ & Individual country central bank authorities & Individual countries' central bank websites \\
\hline & & Individual banks' balance sheets & Bankscope & Bankscope database \\
\hline \multirow[t]{2}{*}{4} & \multirow[t]{2}{*}{$\begin{array}{l}\text { State-owned } \\
\text { enterprises }\end{array}$} & $\begin{array}{l}\text { SOE debt, profit, losses, loan } \\
\text { guarantees, value added, } \\
\text { employment, investment in fixed } \\
\text { capital, among others }\end{array}$ & $\begin{array}{l}\text { WB Public Expenditure Review (Selected } \\
\text { countries only) }\end{array}$ & $\begin{array}{l}\text { http://wbi.worldbank.org/boost/tools-resources/public-expenditure- } \\
\text { review }\end{array}$ \\
\hline & & SOE balance sheets & Individual country authorities & Data is not readily available \\
\hline \multirow{2}{*}{5} & \multirow{2}{*}{ Natural disaster } & $\begin{array}{l}\text { Disaster occurrence/Total damage } \\
(1000 \$)\end{array}$ & EM-DAT & http://www.emdat.be/ \\
\hline & & $\begin{array}{l}\text { World Risk Index } \\
\text { Global Climate Risk Index }\end{array}$ & $\begin{array}{l}\text { UNU-EHS } \\
\text { Germanwatch }\end{array}$ & $\begin{array}{l}\text { http://ehs.unu.edu/news/news/world-risk-report-2014.html } \\
\text { http://germanwatch.org/en/9470 }\end{array}$ \\
\hline 6 & $\begin{array}{l}\text { Demographic } \\
\text { pressures }\end{array}$ & $\begin{array}{l}\text { Aging population/old-age } \\
\text { dependency ratio }\end{array}$ & UN Population Division-WPP & http://esa.un.org/unpd/wpp/Graphs/ \\
\hline 7 & Public sector & $\begin{array}{l}\text { Primary balance, Public debt and } \\
\text { Foreign-currency denominated } \\
\text { public debt as \% to GDP }\end{array}$ & $\begin{array}{l}\text { IMF Art. IV; IFS, WEO, WDI through Haver, } \\
\text { CEIC }\end{array}$ & http://www.imf.org/external/np/sec/aiv/index.aspx?listby=c \\
\hline 8 & $\begin{array}{l}\text { Fragmentation of } \\
\text { governance }\end{array}$ & Government Budget Plans & Individual country authorities & Data not readily available \\
\hline
\end{tabular}

ADO = Asian Development Outlook 2015 Update, Asian Development Bank; EM-DAT = Emergency Events Database, Centre for Research on the Epidemiology of Disasters; GDP $=$ gross domestic product; IFS = International Financial Statistics, International Monetary Fund; OEC = Observatory of Economic Complexity, MIT Media Lab; UN Population Division-WPP = United Nations World Population Prospects; UNU-EHS = United Nations University-Institute for Environment and Human Security; WB = The World Bank; WDI = World Development Indicators, World Bank; WEO = World Economic Outlook October 2015, International Monetary Fund.

Note: Access to Bankscope, CEIC, and Haver databases by subscription.

Source: Authors' compilation. 


\section{REFERENCES}

Adrogue, R. 2005. Fiscal Sustainability: A Value-at-Risk Approach. In M. Rodlauer and A. Schipke, Central America: Global Integration and Regional Cooperation. Occasional Paper 243. Washington, DC: International Monetary Fund.

Asian Development Bank (ADB). 2005. Early Warning Systems of Financial Crises: Applications to East Asia. Manila.

Baldacci, E., I. Petrova, N. Belhocine, G. Dobrescu, and S. Mazraani. 2011. Assessing Fiscal Stress. IMF Working Paper WP/11/100. Washington, DC: International Monetary Fund.

Banca d'Italia, ed. 2008. Fiscal Sustainability: Analytical Developments and Emerging Policy Issues. Public Finance Workshop. Perugia, 3-5 April.

Barnhill, T., and G. Kopits. 2003. Assessing Fiscal Sustainability under Uncertainty. IMF Working Paper WP/03/79, April. Published in 2004 Assessing Fiscal Sustainability under Uncertainty. Journal of Risk. 6 (4). pp. 31-53.

Barnhill, T., A. Masuda, N. Yokobori, and H. Oshgie. 2010. Quantitative Analysis of Debt Sustainability for Indonesia through a Balance Sheet Approach. 23 July. Unpublished.

Barnhill, T., and L. Schumacher. 2011. Modeling Correlated Systemic Liquidity and Solvency Risks in a Financial Environment with Incomplete Information. IMF Working Paper WP/11/263. Washington, DC: International Monetary Fund.

Barnhill, T., and M. Souto. 2009. Systemic Bank Risk in Brazil: A Comprehensive Simulation of Correlated Market, Credit, Sovereign and Inter-Bank Risks. Journal of Financial Markets, Institutions and Instruments. 18 (4). pp. 243-83.

Budina, N., and S. van Wijnbergen. 2009. Quantitative Approaches to Fiscal Sustainability Analysis: A Case Study of Turkey Since the Crisis of 2001. World Bank Economic Review. 22 (1). pp. 119-40.

Burnside, C., ed. 2005. Fiscal Sustainability in Theory and Practice: A Handbook. Washington, DC: World Bank.

Carrasco, B., S. Gokarn, and H. Mukhopadhyay, eds. 2014. Managing Capital Flows: Issues in Selected Emerging Market Economies. Asian Development Bank and Oxford University Press.

Cecchetti, S. G., M. S. Mohanty, and F. Zampoli. 2011. Achieving Growth Amid Fiscal Imbalances: The Real Effects of Debt. In Achieving Maximum Long-Run Growth, a symposium sponsored by the Federal Reserve Bank of Kansas City. Jackson Hole, Wyoming. August. pp. 145-98.

Celasun, O., X. Debrun, and J. D. Ostry. 2006. Primary Surplus Behavior and Risks to Fiscal Sustainability in Emerging Market Countries: A "Fan-Chart" Approach. IMF Working Paper WP/06/67. Washington, DC: International Monetary Fund.

da Costa, E., A. Caputo Silva and W. Baghdassarian. 2004. Assessing Three Models for the Analysis of Debt Sustainability. Getulio Vargas Foundation. April. Unpublished. 
Dornbusch, R. 1998. Capital Controls: An Idea Whose Time is Past. In S. Fischer, R. N. Cooper, R. Dornbusch, P. M. Garber, C. Massad, J. J. Polak, D. Rodrik, S. S. Tarapore, eds. Should the IMF Pursue Capital-Account Convertibility? Essays in International Finance 207. Princeton University Department of Economics.

Easterly, W., and D. Yuravlivker. 2002. Evaluating Government Net Worth in Colombia and Venezuela. In H. Polackova Brixi and A. Schick, eds. Government at Risk: Contingent Liabilities and Fiscal Risk. Washington, DC: World Bank.

Ferrarini, B., R. Jha, and A. Ramayandi, eds. 2012. Public Debt Sustainability in Developing Asia. Asian Development Bank and Routledge.

Ferrarini, B., and A. Ramayandi. 2012. Public Debt Sustainability Assessments for Developing Asia. In B. Ferrarini, R. Jha, and A. Ramayandi, eds. Public Debt Sustainability in Developing Asia. Asian Development Bank and Routledge.

2015. Public Debt Sustainability in Developing Asia: An Update. ADB Economics Working Paper Series No. 468. Manila: Asian Development Bank.

Ferrucci, G., and A. Penalver. 2003. Assessing Sovereign Debt Under Uncertainty. Bank of England. Financial. Stability Review. December. pp. 151-59.

Frank, N., and E. Ley. 2008. Refinements to the Probabilistic Approach to Fiscal Sustainability Analysis. In Banca d'Italia, Fiscal Sustainability: Analytical Developments and Emerging Policy Issues. Public Finance Workshop. Perugia. 3-5 April.

Gapen, M., D. Gray, C. H. Lim, and Y. Xiao. 2008. Measuring and Analyzing Sovereign Risk with Contingent Claims. IMF Staff Papers. 55 (1). pp. 109-48.

Garcia, M., and R. Rigobon. 2004. A Risk Management Approach to Emerging Market's Sovereign Debt Sustainability with an Application to Brazilian Data. NBER Working Papers 10336. Cambridge, MA: National Bureau of Economic Research.

Goldstein, M., G. Kaminsky, and C. Reinhart. 2000. Assessing Financial Vulnerability: Early Warning for Emerging Markets. Washington, DC: Institute for International Economics.

Gray, D., and M. Jones. 2006. Measuring Sovereign and Banking Risk in Indonesia: Application of the Contingent Claims Approach. IMF Country Report No. 6/318. Washington, DC: International Monetary Fund.

Gray, D., and S. Malone. 2008. Macrofinancial Risk Analysis. Chichester: Wiley Finance 2012. Sovereign and Financial Sector Risk: Measurement and Interactions. Annual Review of Financial Economics. 4. pp. 297-312.

Gray, D., R. Merton, and Z. Bodie. 2007. Contingent Claims Approach to Measuring and Managing Sovereign Credit Risk. Journal of Investment Management. 5 (4). pp. 5-28. 
Hausmann, R. 2004. Good Credit Ratios, Bad Credit Ratings: The Role of Debt Structure. In G. Kopits. Ed. Rules-Based Fiscal Policy in Emerging Market Economics: Background, Analysis, and Prospects. New York: Palgrave Macmillan.

International Monetary Fund (IMF). 1996. World Economic Outlook: Focus on Fiscal Policy. Washington, DC.

2002. Assessing Sustainability. 28 May.

2003a. Stability Assessments: Review of Application and Methodological Refinements. 10 June.

. 2003b World Economic Outlook: Public Debt in Emerging Markets. Washington, DC.

2011. Modernizing the Framework for Fiscal Policy and Public Debt Sustainability Analysis. IMF Policy Paper. 5 August.

2013. Staff Guidance Note for Public Debt Sustainability Analysis in Market-Access Countries. 9 May.

—. 2015a. Guidance Note for Surveillance under Article IV Consultations. 19 March.

2015b. Balance Sheet Analysis in Fund Surveillance. 12 June.

Kamenik, O., Z. Tuma, D. Vavra, and Z. Smidova. 2013. A Simple Fiscal Stress Testing Model: Case Studies of Austrian, Czech and German Economies. OECD Economics Department Working Paper No. 1074.

Kopits, G. 2001. Fiscal Policy Rules for India? Economic and Political Weekly. 3 March.

2004. How to Help Europe Cope with Fiscal Risk. Financial Times. 12 November.

2012. Can Fiscal Sovereignty be Reconciled with Fiscal Discipline?. Acta Oeconomica. 62 (2). pp. 141-60.

2014. Coping with Fiscal Risk: Analysis and Practice. OECD Journal on Budgeting. 14 (1). pp. 47-71.

Kopits, G., R. Hagemann, L. Molho, and O. Bjerkholt. 1993. Fiscal Rules in Indonesia: Analysis and Reform Proposals" Fiscal Affairs Department, International Monetary Fund. March.

Kopits, G., R. Holzmann, G. Schieber, and E. Sidgwick. 1990. Social Security Reform in Hungary. Fiscal Affairs Department, International Monetary Fund. October.

Manasee, P., N. Roubini, and A. Schimmelpfennig. 2003. Predicting Sovereign Debt Crises. IMF Working Paper WP/03/221. Washington, DC: International Monetary Fund.

Medina, L. 2015. Assessing Fiscal Risks in Bangladesh. IMF Working Paper WP/15/10. Washington, DC: International Monetary Fund. 
Mendoza, E. G., and P. M. Oviedo. 2004. Public Debt, Fiscal Solvency and Macroeconomic Uncertainty in Latin America: The Cases of Brazil, Colombia, Costa Rica, and Mexico. Working Paper 10637. Cambridge, MA: National Bureau of Economic Research.

2006. Fiscal Policy and Macroeconomic Uncertainty in Developing Countries: The Tale of the Tormented Insurer. Working Paper 12586. Cambridge, MA: National Bureau of Economic Research.

Merton, R. C. 1973. Theory of Rational Option Pricing. Bell Journal of Economics and Management Science. 4 (Spring). pp. 141-83.

- 1974. On the Pricing of Corporate Debt: The Risk Structure of Interest Rates. Journal of Finance. 29 (May). pp. 449-70.

Mussa, M., and A. Richards. 2000. Capital Flows in the 1990s Before and After the Asian Crisis. Greek Economic Review. Autumn.

Park, D., S.-H. Lee, and M. Lee. 2015. Inequality, Inclusive Growth, and Fiscal Policy in Asia. Routledge.

Polackova Brixi, H., and A. Schick, eds. 2002. Government at Risk: Contingent Liabilities and Fiscal Risk. Washington, DC: World Bank.

Reinhart, C., and K. Rogoff. 2009. This Time is Different: Eight Centuries of Financial Folly. Princeton University Press.

United Kingdom, Office for Budget Responsibility. 2012. Briefing Paper No. 4: How We Present Uncertainty. June.

-2015. Fiscal Sustainability Report. Controller of Her Majesty’s Stationery Office. June.

Xu, D., and P. Ghezzi. 2003. From Fundamentals to Spreads: A Fair Spread Model for High Yield Emerging Sovereigns. Manuscript. Deutsche Bank. July. 


\section{Exploring Risk-Adjusted Fiscal Sustainability Analysis for Asian Economies}

The paper explores risk-based fiscal analytical approaches to deal with risk and uncertainty when conducting debt sustainability analysis. It examines the types of vulnerability faced by emerging Asian economies and reviews a range of stochastic methods to incorporate the risks in a framework of fiscal sustainability analysis.

\section{About the Asian Development Bank}

ADB's vision is an Asia and Pacific region free of poverty. Its mission is to help its developing member countries reduce poverty and improve the quality of life of their people. Despite the region's many successes, it remains home to the majority of the world's poor. ADB is committed to reducing poverty through inclusive economic growth, environmentally sustainable growth, and regional integration.

Based in Manila, ADB is owned by 67 members, including 48 from the region. Its main instruments for helping its developing member countries are policy dialogue, loans, equity investments, guarantees, grants, and technical assistance. 